\title{
Production, milk iodine, and nutrient utilization in Jersey cows supplemented with the brown seaweed Ascophyllum nodosum (kelp meal) during the grazing season
}

\author{
N. T. Antaya, ${ }^{1}$ M. Ghelichkhan, ${ }^{1}$ A. B. D. Pereira, ${ }^{1 *}$ K. J. Soder,${ }^{2}$ and A. F. Brito ${ }^{1} \dagger$ \\ ${ }^{1}$ Department of Agriculture, Nutrition, and Food Systems, University of New Hampshire, Durham 03824 \\ ${ }^{2}$ USDA Agricultural Research Service, Pasture Systems and Watershed Management Research Unit, University Park, PA 16802
}

\section{ABSTRACT}

Kelp meal (KM) is a supplement made from the brown seaweed Ascophyllum nodosum, known to bioaccumulate iodine (I) and to be the richest source of phlorotannins, which can inhibit ruminal proteolysis and microbial growth. The objective of this study was to investigate the effects of KM on production, milk I, concentrations of blood metabolites, apparent total-tract digestibility of nutrients, and $\mathrm{CH}_{4}$ emissions in grazing dairy cows. Eight multiparous Jersey cows averaging (mean $\pm \mathrm{SD}$ ) $175 \pm 60 \mathrm{~d}$ in milk and 12 primiparous Jersey cows averaging $142 \pm 47 \mathrm{~d}$ in milk at the beginning of the study were assigned to either $0 \mathrm{~g} / \mathrm{d}$ of KM (control diet, CTRL) or $113 \mathrm{~g} / \mathrm{d}$ of KM (brown seaweed diet, BSW) in a randomized complete block design. Diets were formulated to yield a 70:30 forage-to-concentrate ratio and consisted of (dry matter basis): $48 \%$ cool-season perennial herbage and 52\% partial TMR (pTMR). Each experimental period $(\mathrm{n}=$ 3) lasted $28 \mathrm{~d}$, with data and sample collection taking place during the last $7 \mathrm{~d}$ of each period. Cows had approximately $16.5 \mathrm{~h}$ of access to pasture daily. Herbage dry matter intake increased, and total dry matter intake tended to increase in cows fed BSW versus the CTRL diet. Milk yield and concentrations and yields of milk components were not affected by diets. Similarly, blood concentrations of cortisol, glucose, fatty acids, and thyroxine did not change with feeding CTRL or BSW. However, a diet $\times$ period interaction was observed for milk I concentration; cows offered the BSW diet had greater milk I concentration during periods 1, 2 , and 3, but the largest difference between BSW and CTRL was observed in period 2 (579 vs. $111 \mu \mathrm{g} / \mathrm{L}$, respectively). Except for period 2, the concentration

Received February 12, 2019.

Accepted May 8, 2019.

*Present address: Adisseo USA Inc., Alpharetta, GA 30022.

†Corresponding author: andre.brito@unh.edu of milk I in cows fed KM did not exceed the $500 \mu \mathrm{g} / \mathrm{L}$ threshold recommended for human consumption. Diet $\times$ period interactions were also found for serum triiodothyronine concentration, total-tract digestibilities of crude protein and acid detergent fiber, $\mathrm{CH}_{4}$ production, and urinary excretion of purine derivatives. Overall, the lack of KM effects on milk yield and concentrations and yields of milk components indicate that dairy producers should consider costs before making KM supplementation decisions during the grazing season. Future research is needed to evaluate the concentration of $\mathrm{I}$ in retail organic milk because of the high prevalence of KM supplementation in northeastern and midwestern US organic dairies and possibly in other regions of the country.

Key words: organic agriculture, milk yield, pasture, supplementation

\section{INTRODUCTION}

The brown seaweed Ascophyllum nodosum is one of the most used and studied macroalga species in agriculture (Allen et al., 2001; Makkar et al., 2016). In addition to high concentrations of iodine (I) and other minerals, $A$. nodosum is known to contain a wide spectrum of bioactive compounds, including polysaccharides, PUFA, antioxidants, peptides, and vitamins (Antaya et al., 2015; Makkar et al., 2016). Ascophyllum nodosum is also the richest known source of phlorotannins (PT), which resemble terrestrial tannins in their ability to bind proteins and carbohydrates (Ragan and Glombitza, 1986; Connan et al., 2004), and to inhibit pathogenic bacteria (Wang et al., 2009; Belanche et al., 2016a; Zhou et al., 2018) and ruminal archaea (Belanche et al., 2016a; Zhou et al., 2018). Phlorotannins can also reduce $\mathrm{N}$ output to the environment by reducing ruminal proteolysis and $\mathrm{NH}_{3}-\mathrm{N}$ formation (Wang et al., 2008; Zhou et al., 2018).

Dried and ground $A$. nodosum, commonly known as kelp meal (KM), is available commercially as a supplement for livestock (Allen et al., 2001; Antaya et al., 
2015; Makkar et al., 2016). Surveys revealed that 49, 58 , and $83 \%$ of organic dairy producers feed $\mathrm{KM}$ in Wisconsin (Hardie et al., 2014), the northeastern US (Antaya et al., 2015), and Minnesota (Sorge et al., 2016a), respectively. Organic dairy producers have attributed the following benefits to KM (Antaya et al., 2015): (1) improved BCS and overall animal appearance, (2) decreased milk SCC, reproductive problems, and incidence of "pinkeye" (infectious bovine keratoconjunctivitis), and (3) control of nuisance flies. However, scientific data to support these anecdotal claims are limited. Although previous studies evaluated the effects of $\mathrm{KM}$ on milk yield, heat stress, and animal health in confined dairy cows (Cvetkovic et al., 2004; Kellogg et al., 2006; Pompeu et al., 2011; Antaya et al., 2015), we are not aware of any research that has investigated the effects of KM on production, nutrient utilization, and I metabolism during the grazing season.

Ascophyllum nodosum is known to bioaccumulate I (MacArtain et al., 2007), resulting in I concentrations of $820 \mathrm{mg} / \mathrm{kg}$ of DM (Antaya et al., 2015) or greater (Allen et al., 2001). A linear increase in milk I, which averaged $177,602,1,015$, and $1,370 \mu \mathrm{g} / \mathrm{L}$ in cows fed, respectively, $0,57,113$, and $170 \mathrm{~g} / \mathrm{d}$ of $\mathrm{KM}$ was observed in dairy cows during the winter season (Antaya et al., 2015). Even though KM supplementation has potential to mitigate I deficiency in humans via milk consumption (Brito, 2017), there are concerns of excess I intake particularly for children (IOM, 2001; Zimmermann et al., 2005). Currently, no conclusive standards exist for I levels in milk, but a maximum of $500 \mu \mathrm{g} / \mathrm{L}$ has been advised (EFSA, 2013). Goitrogens such as glucosinolates (GLS) and hydrogen cyanide present in plants may prevent milk I concentration from exceeding $500 \mu \mathrm{g} / \mathrm{L}$ in grazing cows fed KM through competitive inhibition of I transportation into the thyroid and mammary glands (De La Vieja et al., 2000; Osman et al., 2013). Supplementation of $113 \mathrm{~g} / \mathrm{d}$ of KM to dairy cows is within levels reported in the literature (Pompeu et al., 2011; Karatzia et al., 2012; Antaya et al., 2015) and recommended by companies (e.g., Thorvin Inc., New Castle, VA; http://thorvin.com/products/ livestock; accessed March 28, 2019).

Our central hypothesis is that milk I concentration would increase in dairy cows fed $113 \mathrm{~g} / \mathrm{d}$ of KM due to elevated I intake, but the presence of goitrogens such as GLS in grazed herbage would prevent I in milk from surpassing $500-\mu \mathrm{g} / \mathrm{L}$. We further hypothesize that the antimicrobial and antioxidant properties of KM might enhance milk yield through reduction of methanogenesis and improvement of $\mathrm{N}$ utilization and animal health. We aimed to investigate the effects of KM on production, iodine metabolism, apparent total-tract di- gestibility of nutrients, markers of animal health (e.g., cortisol), and $\mathrm{CH}_{4}$ emissions in grazing Jersey cows.

\section{MATERIALS AND METHODS}

Care and handling of the animals used in the current study were conducted as outlined in the guidelines of the University of New Hampshire Institutional Animal Care and Use Committee (Protocol no. 120504). This study was conducted at the University of New Hampshire Burley-Demeritt Organic Dairy Research Farm (Lee; $43^{\circ} 10^{\prime} \mathrm{N}, 70^{\circ} 99^{\prime} \mathrm{W}$ ) from June 13 to October 2, 2012. However, except for milk SCC and milk SCS, all remaining data presented herein were from June 13 to September 4, 2012, because in the last experimental period (September 5 to October 2, 2012) cows had access to pasture only after the afternoon milking. Environmental temperature and relative humidity averaged $19.3^{\circ} \mathrm{C}$ (minimum $=1.3^{\circ} \mathrm{C}$; maximum $=34^{\circ} \mathrm{C}$ ) and $74.8 \%$ (minimum $=26.1 \%$; maximum $=$ $100 \%)$, respectively. These records were collected by the National Centers for Environmental Information (US Department of Commerce-National Oceanic and Atmospheric Administration) weather station located at the University of New Hampshire Kingman Farm (Madbury; $43^{\circ} 17^{\prime} \mathrm{N}, 70^{\circ} 93^{\prime} \mathrm{W}$ ), $12 \mathrm{~km}$ away from the experimental site.

\section{Animals, Experimental Design, and Treatments}

Eight multiparous organic-certified Jersey cows averaging (mean $\pm \mathrm{SD}$ ) $175 \pm 60 \mathrm{DIM}, 20.4 \pm 2.05 \mathrm{~kg} / \mathrm{d}$ of milk, and $441 \pm 30 \mathrm{~kg}$ of $\mathrm{BW}$, and 12 primiparous organic-certified Jersey cows averaging $142 \pm 47$ DIM, $20.6 \pm 2.85 \mathrm{~kg} / \mathrm{d}$ of milk, and $389 \pm 33 \mathrm{~kg}$ of BW at the beginning of the study were used in a randomized complete block design. Cows were blocked in pairs $(\mathrm{n}=$ 10 pairs) according to DIM and milk yield and, within pairs, randomly assigned to 1 of 2 treatments: $0 \mathrm{~g} / \mathrm{d}$ of KM (control diet, CTRL) or $113 \mathrm{~g} / \mathrm{d}$ of KM (brown seaweed diet, BSW). The KM, donated by Thorvin Inc., came from the same lot to minimize variation in nutritional composition. Diets were formulated to yield a 70:30 forage:concentrate ratio using the NRC (2001) ration evaluation software and consisted (DM basis) of $48 \%$ cool-season perennial herbage and $52 \%$ partial TMR (pTMR). The pTMR contained (DM basis) $42.1 \%$ mixed (mostly grass) baleage, $56 \%$ ground corn-barley-based concentrate blend, and $1.9 \%$ sugarcane liquid molasses. Total supplement DMI included pTMR plus pelleted grains used to deliver $\mathrm{Cr}_{2} \mathrm{O}_{3}$ or to attract cows to the portable head chamber gas emission monitoring (GEM) unit (GreenFeed; C-Lock Inc., 
Rapid City, SD). The baleage used in the pTMR was harvested and preserved in plastic-wrapped bales as described previously (Antaya et al., 2015; Resende et al., 2015). Animals assigned to CTRL averaged (mean \pm SD) $155 \pm 55$ DIM, $20.2 \pm 2.79 \mathrm{~kg}$ of milk/d, and 420 $\pm 44 \mathrm{~kg}$ of BW, and those assigned to BSW averaged $156 \pm 55$ DIM, $20.8 \pm 2.30 \mathrm{~kg}$ of milk/d, and $400 \pm 36$ $\mathrm{kg}$ of BW at the beginning of the study. The study was conducted throughout the grazing season (112 d total), with each experimental period lasting $28 \mathrm{~d}$. Data and sample collection presented herein took place in the last $7 \mathrm{~d}$ of each period as follows: period 1 (P1: June 13 to July 10; sampling: July 4 to 10), period 2 (P2: July 11 to August 7; sampling: August 1 to 7), and period 3 (P3: August 8 to September 4; sampling: August 29 to September 4). Cows had free access to water for the duration of the study. The nutritional compositions of herbage and other individual feeds are presented in Tables 1 and 2, respectively. The nutritional and ingredient compositions of pTMR, concentrate blend, and pellets are presented in Table 2 .

\section{Management of Cows}

Cows were milked twice daily at approximately 0430 and $1500 \mathrm{~h}$, and milk weights were recorded throughout the experiment. A chlorhexidine-based teat solution was used for pre- and postdipping. Management of cows after milking, access to pasture, and strip grazing protocol followed procedures reported by Brito et al. (2017). The pTMR was prepared fresh $(\sim 1500 \mathrm{~h})$ to last for 2 feeding events (afternoon of the same day and next morning) using a vertical mixer (V-Mix 400, ValMetal, Tomah, WI) and offered immediately after the afternoon $(\sim 1600 \mathrm{~h})$ or morning $(\sim 0600 \mathrm{~h})$ milking using Calan doors (American Calan Inc., Northwood, $\mathrm{NH}$ ) to individualize intake. Half of the daily amount of $\mathrm{KM}$ was mixed with $227 \mathrm{~g}$ of concentrate blend, placed in rubber tubs inside the Calan doors (American Calan Inc.), and offered to cows before the morning and afternoon milkings, resulting in a daily total of $113 \mathrm{~g}$ of KM and $454 \mathrm{~g}$ of concentrate blend. The concentrate blend was used as a carrier to stimulate complete consumption of KM, which was confirmed visually. Cows in the CTRL diet also received $454 \mathrm{~g}$ of concentrate blend split into 2 portions following the same procedures used to deliver KM. The daily amount of concentrate blend $(454 \mathrm{~g} \times 20$ cows $=9.1 \mathrm{~kg})$ was subtracted from the batch used to make the pTMR to keep diets as formulated. Orts were weighed daily at approximately 1400 h.

In the first 3 wk of each experimental period, cows used in the study $(\mathrm{n}=20)$ and remaining lactating animals of the herd $(\sim 30)$ grazed together in a single group. During each sampling week of P1, P2, and P3, cows assigned to the study grazed separately from nonstudy animals. Cows had approximately $16.5 \mathrm{~h} / \mathrm{d}$ of access to pasture and were weighed for 3 consecutive days before the beginning of the experiment and during the last $3 \mathrm{~d}$ of each period to calculate daily $\mathrm{BW}$ change. Body condition score was assigned to each cow by 2 independent individuals on the last day of P1, P2, and P3, using a 1 to 5 scale (Wildman et al., 1982).

Chromium sequisoxide $\left(\mathrm{Cr}_{2} \mathrm{O}_{3}\right.$; City Chemical LCC, West Haven, CT) was incorporated by Morrison's Custom Feeds (Barnet, VT) into a pelleted feed to be used as the external marker to estimate fecal output of DM as done by Isenberg et al. (2019). A comparable amount of the concentrate blend used in the pTMR was substituted (DM basis) by $1.6 \mathrm{~kg} / \mathrm{d}$ of $\mathrm{Cr}_{2} \mathrm{O}_{3}$-containing pellet to maintain diets as formulated. This pellet was offered twice daily $(0.8 \mathrm{~kg} /$ feeding $)$ in rubber tubs placed inside the Calan doors (American Calan Inc.) immediately before the morning and afternoon milkings during the last $10 \mathrm{~d}$ of $\mathrm{P} 1, \mathrm{P} 2$, and $\mathrm{P} 3$ to ensure complete consumption, which was confirmed visually. Concentration of $\mathrm{Cr}$ in the pellet averaged (mean \pm SD) $3,962 \pm 387 \mathrm{mg} / \mathrm{kg}$, with estimated Cr intake of $5.41 \mathrm{~g} /$ cow daily. Cows also had access to a GEM unit mounted in a trailer equipped with solar panels (GreenFeed; C-Lock Inc.) throughout the experiment for collection of spot short-term gaseous measurements $\left(\mathrm{CH}_{4}\right.$ and $\left.\mathrm{CO}_{2}\right)$. The GEM unit was placed near the cows in each paddock to encourage visitation and occasionally inside the barn to collect gaseous data when cows were not grazing. Calibrations, gaseous analyses, and detailed methodology related to GEM operation can be found elsewhere (Dorich et al., 2015; Hammond et al., 2015; Gunter and Beck, 2018).

\section{Herbage and Feed Sampling and Analyses}

Herbage samples were collected each time cows were moved to a new strip of fresh pasture during each sampling collection week in P1 to P3. For determination of pre- and postgrazing herbage mass ( $\mathrm{kg}$ of DM/ha) and sward botanical composition, herbage was collected to approximately $2 \mathrm{~cm}$ above ground using scissors or knives, which is within the range reported in the literature (Pérez-Prieto and Delagarde, 2012). Quadrats $\left(0.25 \mathrm{~m}^{2}\right)$ were used to delimitate the area to collect herbage samples at 20 random locations of each paddock in a "zig-zag" pattern. Paddocks were mapped via GPS (Garmin Ltd., Olathe, KS), with 1- to 2-m range accuracy, to record the area $\left(\mathrm{m}^{2}\right)$ to be grazed. Samples for nutritional analyses were collected using the handplucking method of Kolver and Muller (1998). Herbage samples for botanical composition were sorted into 
grasses, legumes, weeds, and dead materials. Predominant herbage species were identified concurrently with samples used for botanical composition and included: orchardgrass (Dactylis glomerata L.), white clover (Trifolium repens L.), smooth bromegrass (Bromus inermis
Leyss.), perennial ryegrass (Lolium perenne L.), and tall fescue (Festuca arundinacea Schreb.). All samples were dried at $55^{\circ} \mathrm{C}$ in a forced-air oven (VWR Scientific, Bridgeport, NJ) for about 48 h. Herbage height (pre- and postgrazing) was determined using a ruler,

Table 1. Environmental conditions; herbage mass, height, allowance, and nutritional profile; and sward botanical composition throughout the grazing season

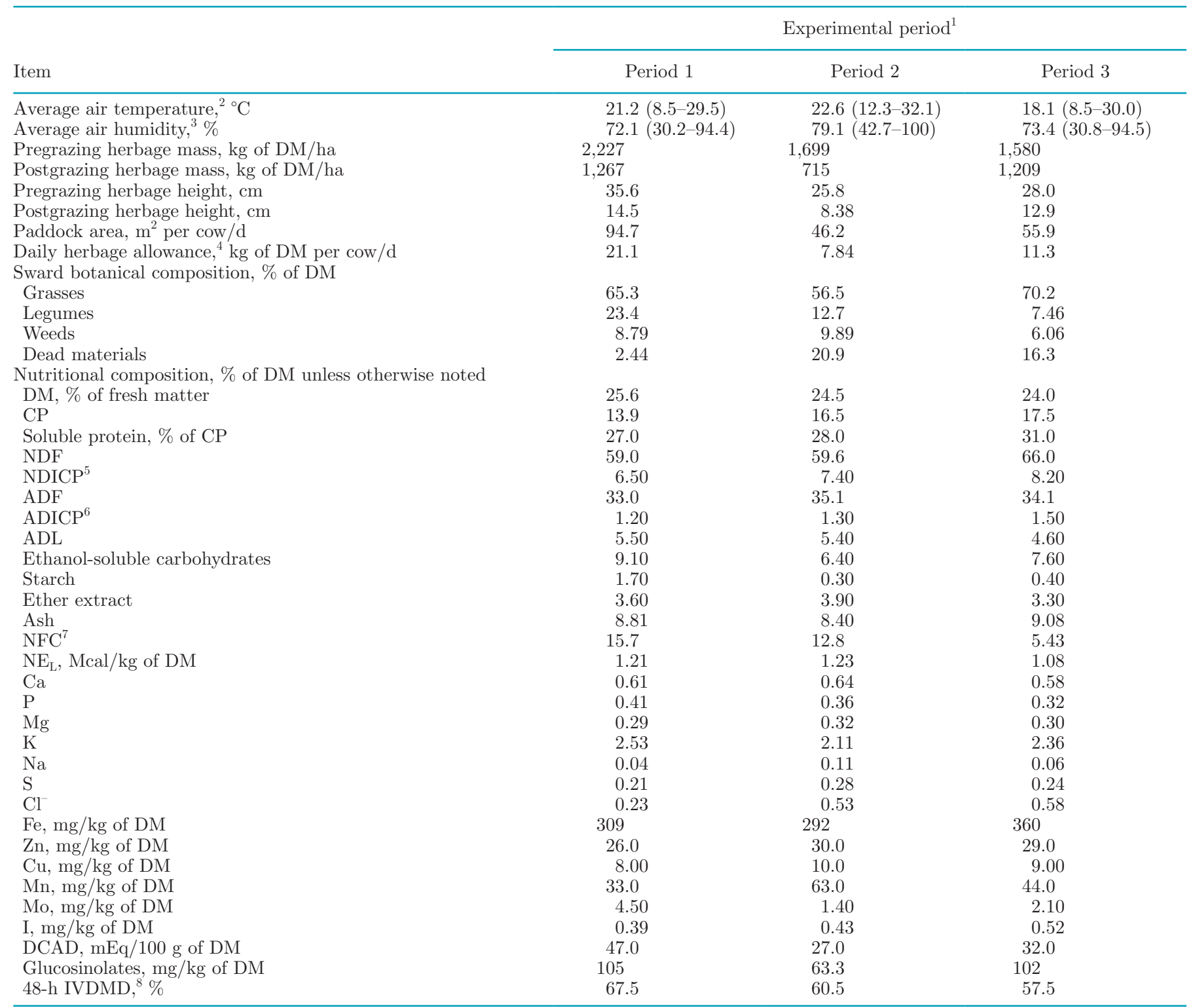

${ }^{1}$ Period 1 = June 13 to July 10, sampling July 4 to 10; Period $2=$ July 11 to August 7, sampling August 1 to 7; Period $3=$ August 8 to September 4, sampling August 29 to September 4.

${ }^{2}$ Values in parentheses indicate minimum and maximum air temperatures $\left({ }^{\circ} \mathrm{C}\right)$, respectively.

${ }^{3}$ Values in parentheses indicate minimum and maximum air relative humidity (\%), respectively.

${ }^{4}$ Daily herbage allowance $=\left[\right.$ pregrazing herbage mass $(\mathrm{kg}$ of DM/ha $) \times$ pasture area $\left(\mathrm{m}^{2} /\right.$ cow per day $\left.)\right] / 10,000$.

${ }^{5} \mathrm{NDICP}=$ neutral detergent insoluble $\mathrm{CP}$

${ }^{6} \mathrm{ADICP}=$ acid detergent insoluble $\mathrm{CP}$.

${ }^{7} \mathrm{NFC}=100-[\mathrm{CP}+(\mathrm{NDF}-\mathrm{NDICP})+$ ether extract + ash $]$.

${ }^{8} \mathrm{IVDMD}=$ in vitro DM digestibility. 
and 15 height measurements per transect $(\mathrm{n}=3 /$ paddock) were taken as reported previously (Brito et al., 2017).

Concentrate blend and $\mathrm{Cr}_{2} \mathrm{O}_{3}$-containing pellet samples were taken once per period during the sampling week of P1, P2, and P3 for nutrient analyses. Samples of KM ( $\mathrm{n}=1$ /each bag opened), sugarcane liquid molasses $(n=1 /$ tote $)$, and GEM pellet $(n=1$ / period) were collected and composited across the study.
All bales were sampled ( $\sim 200 \mathrm{~g}$ of baleage/bale) using an electric drill (model TE 7-A; Hilti Inc., Tulsa, OK) fitted with a $45-\mathrm{cm}$ stainless steel core sampler barrel (Nasco, Fort Atkinson, WI). Samples of pTMR and orts (from all 20 cows unless pTMR was entirely consumed) were collected daily during each sampling week. Feed and ort samples were dried for $48 \mathrm{~h}$ in a forced-air oven at $55^{\circ} \mathrm{C}$ (VWR International), with baleage DM used to adjust daily the as-fed proportion

Table 2. Nutritional composition (\% of DM unless otherwise noted) of mixed (mostly grass) baleage, concentrate blend, sugarcane liquid molasses, partial TMR (pTMR), kelp meal (KM), $\mathrm{Cr}_{2} \mathrm{O}_{3}$-containing pellet, and gas emission monitoring (GEM) unit pellet

\begin{tabular}{|c|c|c|c|c|c|c|c|}
\hline Item & $\begin{array}{c}\text { Mixed grass } \\
\text { baleage }\end{array}$ & $\begin{array}{c}\text { Concentrate } \\
\text { blend }^{1}\end{array}$ & $\begin{array}{l}\text { Liquid } \\
\text { molasses }\end{array}$ & pTMR & $\mathrm{KM}$ & $\begin{array}{l}\mathrm{Cr}_{2} \mathrm{O}_{3} \\
\text { pellet }^{2}\end{array}$ & $\begin{array}{l}\text { GEM } \\
\text { pellet }^{3}\end{array}$ \\
\hline DM, $\%$ of fresh matter & $60.4 \pm 7.90$ & $91.0 \pm 0.15$ & 75.0 & $72.0 \pm 9.05$ & 91.9 & $91.7 \pm 1.48$ & 91.6 \\
\hline $\mathrm{CP}$ & $12.2 \pm 0.12$ & $12.2 \pm 0.32$ & 5.10 & $12.1 \pm 0.17$ & 10.3 & $18.1 \pm 0.23$ & 17.7 \\
\hline Soluble protein, $\%$ of CP & $51.3 \pm 8.02$ & $26.7 \pm 2.08$ & - & $36.9 \pm 4.59$ & 54.0 & $29.7 \pm 0.58$ & 35.0 \\
\hline NDF & $62.3 \pm 2.26$ & $10.3 \pm 2.74$ & - & $32.0 \pm 2.32$ & 39.2 & $18.9 \pm 3.99$ & 17.0 \\
\hline $\mathrm{NDICP}^{4}$ & $2.27 \pm 0.70$ & $1.50 \pm 0.20$ & - & $1.79 \pm 0.36$ & 5.60 & $2.73 \pm 0.15$ & 2.10 \\
\hline $\mathrm{ADF}$ & $42.5 \pm 0.90$ & $3.77 \pm 1.50$ & - & $20.0 \pm 1.17$ & 20.8 & $8.40 \pm 1.73$ & 10.0 \\
\hline $\mathrm{ADICP}^{5}$ & $1.37 \pm 0.29$ & $0.33 \pm 0.06$ & - & $0.76 \pm 0.11$ & 5.10 & $0.53 \pm 0.15$ & 1.10 \\
\hline $\mathrm{ADL}$ & $5.93 \pm 0.75$ & $1.57 \pm 0.55$ & - & $3.38 \pm 0.62$ & 12.2 & $3.20 \pm 0.44$ & 3.20 \\
\hline Ethanol-soluble carbohydrates & $5.40 \pm 0.69$ & $3.10 \pm 1.68$ & 78.0 & $5.49 \pm 1.23$ & 3.90 & $4.53 \pm 1.23$ & 4.30 \\
\hline Starch & $1.47 \pm 1.07$ & $57.4 \pm 0.25$ & - & $32.8 \pm 0.34$ & 0.40 & $40.2 \pm 0.98$ & 41.2 \\
\hline Ether extract & $2.93 \pm 0.31$ & $2.23 \pm 0.15$ & 2.20 & $2.53 \pm 0.04$ & 2.40 & $2.90 \pm 0.53$ & 3.00 \\
\hline Ash & $6.54 \pm 0.15$ & $8.22 \pm 0.63$ & 14.7 & $7.64 \pm 0.31$ & 26.1 & $10.1 \pm 0.10$ & 8.72 \\
\hline $\mathrm{NE}_{\mathrm{L}}, \mathrm{Mcal} / \mathrm{kg}$ of $\mathrm{DM}$ & $1.12 \pm 0.07$ & $1.82 \pm 0.05$ & 1.85 & $1.53 \pm 0.05$ & 0.84 & $1.79 \pm 0.08$ & 1.74 \\
\hline $\mathrm{NFC}^{6}$ & $16.4 \pm 2.14$ & $67.3 \pm 3.61$ & - & $44.6 \pm 2.63$ & 22.9 & $50.4 \pm 3.68$ & 53.9 \\
\hline $\mathrm{Ca}$ & $0.83 \pm 0.04$ & $0.98 \pm 0.07$ & 0.58 & $0.91 \pm 0.02$ & 1.28 & $1.24 \pm 0.09$ & 1.07 \\
\hline $\mathrm{P}$ & $0.39 \pm 0.01$ & $0.59 \pm 0.07$ & 0.09 & $0.50 \pm 0.04$ & 0.21 & $0.45 \pm 0.01$ & 0.43 \\
\hline $\mathrm{Mg}$ & $0.27 \pm 0.02$ & $0.66 \pm 0.09$ & 0.27 & $0.49 \pm 0.06$ & 0.80 & $0.46 \pm 0.02$ & 0.38 \\
\hline $\mathrm{K}$ & $0.21 \pm 0.01$ & $0.53 \pm 0.04$ & 5.82 & $0.50 \pm 0.03$ & 2.57 & $0.86 \pm 0.02$ & 0.80 \\
\hline $\mathrm{Na}$ & $2.08 \pm 0.08$ & $1.10 \pm 0.12$ & 0.16 & $1.50 \pm 0.10$ & 3.59 & $0.93 \pm 0.01$ & 0.74 \\
\hline $\mathrm{S}$ & $2.10 \pm 0.46$ & $0.24 \pm 0.02$ & 0.82 & $1.03 \pm 0.20$ & 2.71 & $0.22 \pm 0.01$ & 0.20 \\
\hline $\mathrm{Cl}^{-}$ & $0.17 \pm 0.02$ & $1.09 \pm 0.05$ & - & $0.68 \pm 0.02$ & 4.73 & $1.00 \pm 0.03$ & 0.87 \\
\hline $\mathrm{Fe}, \mathrm{mg} / \mathrm{kg}$ of DM & $0.12 \pm 0.07$ & $412 \pm 76.9$ & 347 & $238 \pm 43.1$ & 403 & $413 \pm 59.0$ & 292 \\
\hline $\mathrm{Zn}, \mathrm{mg} / \mathrm{kg}$ of DM & $127 \pm 28.8$ & $147 \pm 36.7$ & 7.00 & $136 \pm 11.3$ & 11.0 & $161 \pm 5.20$ & 141 \\
\hline $\mathrm{Cu}, \mathrm{mg} / \mathrm{kg}$ of DM & $25.3 \pm 1.15$ & $22.7 \pm 4.51$ & 12.0 & $23.6 \pm 2.54$ & 4.00 & $27.7 \pm 3.06$ & 22.0 \\
\hline $\mathrm{Mn}, \mathrm{mg} / \mathrm{kg}$ of DM & $8.00 \pm 1.00$ & $103 \pm 23.2$ & 23.0 & $61.3 \pm 12.7$ & 24.0 & $116 \pm 5.57$ & 96.0 \\
\hline $\mathrm{Mo}, \mathrm{mg} / \mathrm{kg}$ of DM & $39.3 \pm 7.09$ & $1.10 \pm 0.10$ & 1.10 & $17.2 \pm 2.95$ & 0.90 & $1.27 \pm 0.06$ & 1.10 \\
\hline $\mathrm{Cr}, \mathrm{mg} / \mathrm{kg}$ of DM & - & - & - & $0.94 \pm 0.64$ & 0.95 & $3,962 \pm 387$ & - \\
\hline $\mathrm{I}, \mathrm{mg} / \mathrm{kg}$ of $\mathrm{DM}$ & $0.45 \pm 0.38$ & 2.65 & - & $1.67 \pm 0.16$ & 727 & - & - \\
\hline DCAD, mEq/100 g of DM & $0.42 \pm 0.09$ & $16.0 \pm 3.61$ & - & $9.14 \pm 1.99$ & -80.0 & $20.3 \pm 0.58$ & 16.0 \\
\hline Glucosinolates, $\mathrm{mg} / \mathrm{kg}$ of DM & $32.9 \pm 16.0$ & 80.1 & - & $58.7 \pm 6.72$ & - & - & - \\
\hline 48-h IVDMD, ${ }^{7} \%$ & - & - & - & $73.9 \pm 1.78$ & - & - & - \\
\hline
\end{tabular}

${ }^{1}$ Consisted (DM basis) of $52 \%$ ground corn, $20.7 \%$ barley, $10 \%$ wheat, $5.77 \%$ field peas, $4 \%$ soybean meal, $1.55 \%$ NaCl, $1.50 \%$ sodium bicarbonate, 1.33\% limestone, 1.12\% DIKAL 21 (19\% Ca and 21\% P; Amax Phosphate Inc., Greenwich, CT), 0.98\% magnesium oxide, 0.32\% potassium sulfate, $0.17 \%$ Se, $0.33 \%$ mineral premix, and $0.28 \%$ A-D-E vitamin premix. The mineral premix provided (guaranteed analysis) $30 \%$ of Ca, 790 $\mathrm{mg} / \mathrm{kg}$ of I, $675 \mathrm{mg} / \mathrm{kg}$ of Co, $6.0 \mathrm{~g} / \mathrm{kg}$ of $\mathrm{Cu}, 4.0 \%$ of $\mathrm{Zn}$, and $2.5 \%$ of Mn. The A-D-E vitamin premix provided (guaranteed analysis) $6,062,721$ $\mathrm{IU} / \mathrm{kg}$ of vitamin A, 1,653,450 IU $/ \mathrm{kg}$ of vitamin $\mathrm{D}$, and $25,353 \mathrm{IU} / \mathrm{kg}$ of vitamin $\mathrm{E}$.

${ }^{2}$ Consisted (DM basis) of $38 \%$ ground corn, $5.68 \%$ wheat, $10 \%$ field peas, $4.72 \%$ soybean meal, $18.5 \%$ wheat middlings, $9 \%$ flaxseed meal, $4 \%$ alfalfa meal, $3 \%$ sugarcane liquid molasses, $1.13 \% \mathrm{NaCl}, 1 \%$ sodium bicarbonate, $2.13 \%$ limestone, $0.45 \%$ magnesium oxide, $0.06 \%$ potassium sulfate, $0.10 \%$ Se, $0.22 \%$ mineral premix, and $0.29 \%$ A-D-E vitamin premix, $0.50 \%$ sodium bentonite, 0.50 Redmond conditioner (Redmond Minerals Inc., West Redmond, UT), and $0.74 \% \mathrm{Cr}_{2} \mathrm{O}_{3}$ (City Chemical LCC, West Haven, CT). The mineral and A-D-E vitamin premixes had the same nutritional composition as those used in the concentrate blend. The Redmond conditioner (Redmond Minerals Inc.) provided (guaranteed analysis) $4-5 \%$ of $\mathrm{Ca}, 0.04 \%$ of $\mathrm{P}, 2.5-3.5 \%$ of $\mathrm{NaCl}, 0.8 \%$ of $\mathrm{Mg}, 0.7 \%$ of $\mathrm{K}, 0.08 \%$ of S, $29 \mathrm{mg} / \mathrm{kg}$ of $\mathrm{Cu}, 3,900 \mathrm{mg} / \mathrm{kg}$ of $\mathrm{Fe}$, and 400 $\mathrm{mg} / \mathrm{kg}$ of $\mathrm{Mn}$.

${ }^{3}$ The ingredient composition of the GEM unit pellet was the same as that of the $\mathrm{Cr}_{2} \mathrm{O}_{3}$-containing pellet except that the amount of $\mathrm{Cr}_{2} \mathrm{O}_{3}$ used was replaced by ground corn.

${ }^{4} \mathrm{NDICP}=$ neutral detergent insoluble $\mathrm{CP}$.

${ }^{5} \mathrm{ADICP}=$ acid detergent insoluble $\mathrm{CP}$.

${ }^{6}$ The formula NFC $=100-[\mathrm{CP}+(\mathrm{NDF}-\mathrm{NDICP})+$ ether extract + ash $]$ was used for baleage, concentrate blend, pTMR, and pellets. The formula $\mathrm{NFC}=100-(\mathrm{CP}+\mathrm{NDF}+$ ether extract + ash $)$ was used for liquid molasses.

${ }^{7} \mathrm{IVDMD}=$ in vitro DM digestibility. 
of baleage in the pTMR. Dried feeds were ground to pass through a 1-mm screen (Wiley mill; Thomas Scientific, Swedesboro, NJ). Herbage, baleage, pTMR, and orts (by treatment) were composited individually by sampling week in each period. Dried weights of pTMR and orts were used to calculate pTMR DMI.

Herbage, baleage, KM, and pellets were shipped to a commercial laboratory (Dairy One Cooperative Inc., Ithaca, NY) and analyzed for DM, total N, soluble protein, NDF, ADF, NDIN, ADIN, ADL, ether extract, ash, individual minerals ( $\mathrm{Ca}, \mathrm{P}, \mathrm{Mg}, \mathrm{K}, \mathrm{Na}, \mathrm{Fe}, \mathrm{Zn}$, $\mathrm{Cu}, \mathrm{Mn}, \mathrm{Mo}, \mathrm{S}, \mathrm{Cl}$ ion), starch, and ethanol soluble carbohydrates following methods reported by Antaya et al. (2015). Pellets, pTMR, and KM were analyzed for $\mathrm{Cr}$ via atomic absorption by Analab (Fulton, IL) according to Williams et al. (1962) and Binnerts et al. (1968). Samples of herbage and baleage collected during each sampling week in P1, P2, and P3 and composited samples of concentrate blend and KM were quantified for I by inductively coupled plasma mass spectrometry at Dartmouth College Trace Element Analysis Laboratory (Hanover, NH). Sugarcane liquid molasses was analyzed for DM, CP, ether extract, ash, and individual minerals at Dairy One Cooperative Inc. as reported by Brito et al. (2017). Total GLS in samples of herbage, baleage, and concentrate blend were determined by HPLC (AOCS, 2011) at Bioprofile Testing Laboratories (St. Paul, MN). Herbage and pTMR were further analyzed for 48-h in vitro DM digestibility (IVDMD) by Cumberland Valley Analytical Services (Hagerstown, MD) using a Daisy II incubator (ANKOM Technology, Fairport, NY). Orts were sent to Dairy One Cooperative Inc. for analyses of DM, CP, $\mathrm{NDF}, \mathrm{ADF}$, and ash according to procedures reported by Antaya et al. (2015).

\section{Milk Sampling and Analyses}

Milk samples were collected during 4 consecutive milkings starting in the afternoon of $\mathrm{d} 1$ of each sampling week and finishing the morning of $\mathrm{d} 3$ in P1, P2, and P3. Samples were composited over each 2 consecutive milkings proportionally to milk yield (afternoon of $\mathrm{d} 1$ and morning of $\mathrm{d} 2=$ composite 1 ; afternoon of $\mathrm{d} 2$ and morning of $\mathrm{d} 3=$ composite 2), preserved with a 2-bromo-2-nitropropane-1,3 diol tablet (D\&F Control Systems Inc., Norwood, MA), and refrigerated at $4^{\circ} \mathrm{C}$ until analysis. Samples were shipped to Dairy One Cooperative Inc. in duplicate per set of composites and analyzed for concentrations (vol/vol) of fat, true protein, lactose, SNF, TS, and MUN by Fourier transform infrared spectroscopy using a MilkoScan model FT+ (Foss Analytics, Hillerød, Denmark). In addition, milk samples from 2 consecutive milkings (afternoon of d 1 and morning of d 2) were collected during each sampling week per period, composited proportionally to milk yield (composite 3 ), and stored at $-20^{\circ} \mathrm{C}$ without preservative until shipped to Michigan State University Veterinary Diagnostic Laboratory (Lansing, MI) for I analysis using inductively coupled plasma mass spectrometry. Milk samples for SCC (flow cytometry with a Fossomatic FC; Foss Inc. at Dairy One Cooperative Inc.) were collected by an independent individual from DHI services on June 13, July 14, August 14, and September 15.

\section{Blood Sampling and Analyses}

Blood was sampled via the coccygeal vein or artery into 10-mL Vacutainer tubes (Becton Dickinson, Franklin Lakes, NJ) using a 20-gauge needle (Monoject; Covidien, Mansfield, MA) once daily at approximately 1630 $\mathrm{h}$ during the first $2 \mathrm{~d}$ of each sampling week in P1 to P3. Vacutainer tubes without anticoagulant were used for measurements of serum cortisol, triiodothyronine $\left(\mathbf{T}_{3}\right)$, and thyroxine $\left(\mathbf{T}_{4}\right)$, and those containing EDTA were analyzed for plasma fatty acids, urea N (PUN), and glucose. Serum was harvested after samples were kept at room temperature until they clotted $(\sim 1 \mathrm{~h})$ followed by centrifugation $\left(3,300 \times g\right.$ for $20 \mathrm{~min}$ at $5^{\circ} \mathrm{C}$; Eppendorf centrifuge model 5810; Eppendorf, Hamburg, Germany). After collection, serum was pooled in equal amounts by cow across sampling times, placed in cryovials, and stored at $-80^{\circ} \mathrm{C}$ until analyses. Blood samples used for harvesting of plasma were centrifuged as done for serum and stored at $-20^{\circ} \mathrm{C}$ in cryovials before being analyzed. Commercially available kits were used to determine the serum concentrations of $\mathrm{T}_{3}$ (RIA, catalog no. TKT3; Siemens Medical Solutions Diagnostics, Los Angeles, CA) and $\mathrm{T}_{4}$ (RIA, catalog no. TKT4; Siemens Medical Solutions Diagnostics) at Kansas State University (Manhattan, KS). Commercial kits were also used to analyze the serum concentration of cortisol (competitive ELISA, immobilized antigen, catalog no. RCAN-C-270R; BioVendor LLC, Asheville, $\mathrm{NC}$ ) and the plasma concentrations of fatty acids [enzymatic colorimetric assay, HR series NEFA-HR(2); Wako Diagnostics, Richmond, VA] and glucose (enzymatic colorimetric assay, catalog no. 510; Sigma-Aldrich, St. Louis, MO). The concentration of PUN was analyzed colorimetrically using the diacetyl monoxime method of Rosenthal (1955).

\section{Urine and Fecal Sampling and Analyses}

Spot urine samples were collected twice daily at approximately 0500 and $1700 \mathrm{~h}$ for 3 consecutive days 
(d 3 to 5 of each sampling week in P1, P2, and P3) during voluntary urination or through stimulation of the pudendal nerve by massaging the area below the vulva. Samples were composited to create 1 sample per cow over $3 \mathrm{~d}$ by mixing $8 \mathrm{~mL}$ of urine and 400 $\mu \mathrm{L}$ of $6 \mathrm{~N} \mathrm{HCl}$ per time collection point. Composited samples were stored at $-20^{\circ} \mathrm{C}$ until later measurements of nitrogenous metabolites. After thawing at room temperature, samples were analyzed colorimetrically for concentrations of creatinine (assay kit, catalog no. 500701; Cayman Chemical Co., Ann Arbor, MI), allantoin (Chen et al., 1992), and uric acid (assay kit, catalog no. 1045-225; Stanbio Laboratory, Boerne, TX), and for total N (micro-Kjeldahl) at Dairy One Cooperative Inc.

Fecal samples were collected twice daily at approximately 0500 and $1700 \mathrm{~h}$ during the last $5 \mathrm{~d}$ of each sampling week in P1, P2, and P3 during voluntary defecation or by rectal grab. Samples were pooled by cow, dried in a forced-air oven $\left(55^{\circ} \mathrm{C}, \sim 72 \mathrm{~h}\right.$; Sheldon Manufacturing Inc., Cornelius, OR), and ground to pass through a 1-mm screen (Wiley mill; Thomas Scientific) until analyzed for DM, CP, ADF, NDF, and ash (Dairy One Cooperative Inc.), and $\mathrm{Cr}$ (Analab).

\section{Respiration Rate and Body Temperature}

Respiration rate and rectal temperature measurements were taken during morning and afternoon milkings for 4 consecutive days (d 3 to 6 ) of each sampling week in P1, P2, and P3. Respiration rates were determined by counting flank movements for 1 min using a digital timer, and body temperatures were obtained using a clinical thermometer inserted approximately 8 $\mathrm{cm}$ into the rectum for about $45 \mathrm{~s}$ to $1 \mathrm{~min}$.

\section{Calculations}

Pre- and postgrazing herbage mass was determined by multiplying the amount of forage within the 0.25 $\mathrm{m}^{2}$ quadrat frame by the total paddock area (ha). Herbage allowance was calculated by multiplying pregrazing herbage mass ( $\mathrm{kg}$ of $\mathrm{DM} / \mathrm{ha}$ ) times the daily pasture area $\left(\mathrm{m}^{2}\right)$ allocated to individual cows divided by 10,000 to convert from square meters to hectares. Herbage DMI was estimated according to Bargo et al. (2002) as follows:

$$
\begin{gathered}
\text { Estimated herbage DMI }(\mathrm{kg} / \mathrm{d})= \\
\left\{\begin{array}{c}
\text { fecal DM output }(\mathrm{kg} / \mathrm{d})-[\mathrm{pTMR} \text { DMI }(\mathrm{kg} / \mathrm{d}) \\
\times 1-\text { pTMR } 48 \text {-h IVDMD }]\} / \\
(1-\text { herbage } 48 \text {-h IVDMD })
\end{array}\right.
\end{gathered}
$$

where fecal DM output was calculated using $\mathrm{Cr}_{2} \mathrm{O}_{3}$ as the external marker with the equation reported by Kolver and Muller (1998):

$$
\begin{gathered}
\text { Fecal output of DM }(\mathrm{kg} / \mathrm{d})= \\
\text { Cr intake }(\mathrm{g} / \mathrm{d}) / \text { fecal } \mathrm{Cr}(\mathrm{g} / \mathrm{kg} \text { of } \mathrm{DM}) .
\end{gathered}
$$

Body weight change was calculated by subtracting mean values obtained in the last $3 \mathrm{~d}$ of $\mathrm{P} 1, \mathrm{P} 2$, and $\mathrm{P} 3$ from those recorded on $\mathrm{d}-3$ to 0 relative to the beginning of the study. Test-day milk SCC was converted to milk SCS using a base-2 logarithmic function as follows: milk SCS $=\log _{2}($ milk SCC $/ 100)+3$ (Ali and Shook, 1980). Daily volume of urine was estimated from the urinary concentration of creatinine, assuming a constant creatinine excretion rate of $0.212 \mathrm{mmol} / \mathrm{kg}$ of BW (Chizzotti et al., 2008). Urinary excretion of allantoin, uric acid, total purine derivatives $(\mathbf{P D}=$ allantoin plus uric acid), and total $\mathrm{N}$ were calculated by multiplying the urinary volume by the concentrations of these individual metabolites in urine. Both $\mathrm{CH}_{4}$ yield and $\mathrm{CH}_{4}$ intensity were calculated by dividing $\mathrm{CH}_{4}$ production (g/d) by total DMI and ECM yield, respectively.

\section{Statistical Analysis}

Data were analyzed according to a randomized complete block design with repeated measures over time using the MIXED procedure of SAS (version 9.4; SAS Institute Inc., Cary, NC) as follows:

$$
\mathrm{Y}_{\mathrm{ijkl}}=\mu+\mathrm{B}_{\mathrm{i}}+\mathrm{D}_{\mathrm{j}}+\operatorname{Per}_{\mathrm{k}}+\mathrm{C}_{\mathrm{l}(\mathrm{i})}+\mathrm{D} \times \mathrm{Per}_{\mathrm{jk}}+\varepsilon_{\mathrm{ijkl}},
$$

where $Y_{\mathrm{ijkl}}=$ dependent variable, $\mu=$ overall mean, $B_{\mathrm{i}}$ = fixed effect of the ith block (pair of cows), $D_{j}=$ fixed effect of the jth diet, $\mathrm{Per}_{\mathrm{k}}=$ fixed effect of the kth period, $\mathrm{C}_{\mathrm{l}(\mathrm{i})}=$ random effect of lth cow within the ith block, $\mathrm{D} \times \mathrm{Per}_{\mathrm{jk}}=$ interaction between the jth diet and kth period, and $\varepsilon_{\mathrm{ijkl}}=$ error term (assumed to be normally distributed with mean $=0$ and constant variance). The SAS command REPEATED was used to model distinct residual variances and, among the covariance structures tested [i.e., spatial power, compound symmetry, autoregressive (1), and heterogeneous autoregressive (1)], the one with the lowest Bayesian information criterion was retained in the final model. The subject of the repeated measures was defined as cow nested within treatment. All reported values are least squares means, with the PDIFF procedure of SAS used to separate treatment means (CTRL vs. BSW diet). We used Tukey's multiple comparison test to adjust least squares means for period and diet $\times$ period interactions. Pre-study milk SCC and milk SCS were used as covariate terms in 
the statistical model to compare the effects of treatments on these 2 variables. Gaseous measurements were analyzed using a model like that reported above, except that initial BW (covariate), parity (block), and the diet $\times$ parity and period $\times$ parity interactions were included. Pair of animals was not used as the block term in the statistical model for gaseous measurements because not all cows visited the GEM unit throughout the study, so that the original pairwise blocking could not be maintained. It should be emphasized that the block term (i.e., pair of animals) was not significant for total DMI, which is known to influence $\mathrm{CO}_{2}$ and $\mathrm{CH}_{4}$ emissions (Casper and Mertens, 2010; Niu et al., 2018). Significance was declared at $P \leq 0.05$ and trends at $0.05<P \leq 0.10$. The covariate and interaction terms were removed from the statistical models when $P>$ 0.25 .

\section{RESULTS AND DISCUSSION}

Most variables analyzed in this study resulted in period effects $(P \leq 0.05)$ and are presented in Tables 3, 4,5 , and 6 . In general, period effects can be explained by changes in herbage nutritional composition, feed intake, DIM, and milk yield, with the progress of the grazing season, and were occasionally discussed herein.

\section{Herbage Mass and Feed Nutritional Composition}

Environmental conditions, herbage mass yield, height, allowance, nutritional profile, and sward botanical composition are presented in Table 1 . The nutritional composition of the remaining feeds is shown in Table 2. Pregrazing herbage mass yield averaged (mean $\pm \mathrm{SD}$ ) 1,835 $\pm 344 \mathrm{~kg}$ of DM/ha. Daily herbage allowance averaged $13.4 \mathrm{~kg}$ of $\mathrm{DM} / \mathrm{cow}$ (ranged from 7.84 to $21.1 \mathrm{~kg}$ of DM/cow) and was $53 \%$ greater than estimated herbage DMI determined through IVDMD and $\mathrm{Cr}_{2} \mathrm{O}_{3}$ (mean $=8.77 \mathrm{~kg} / \mathrm{d}$; Table 3$)$. In addition, residual herbage left after grazing (calculated by dividing postgrazing herbage mass yield by that of pregrazing, and multiplying by 100) averaged $59 \%$. These results suggest that the amount of herbage mass offered appeared to be adequate relative to estimated herbage DMI. Overall, the nutritive value of the herbage offered in this study, including the concentrations of CP, NDF, $\mathrm{ADF}$, and macro- and microminerals, was within the range of that observed previously in the northeastern US (Hafla et al., 2016; Brito et al., 2017; Isenberg et al., 2019).

The concentrations of NDF, ADF, and ADL of KM were, respectively, 37.5, 91.8, and $63.9 \%$ lower than those of KM reported by Antaya et al. (2015). This variation in fiber profile suggests that the fresh $A$. nodosum was harvested in different stages of growth. However, the concentrations of ash $($ mean $=26.1 \%)$ and $\mathrm{I}($ mean $=727 \mathrm{mg} / \mathrm{kg}$ of DM) of the KM supplemented herein was comparable to values reported by Antaya et al. (2015). Herbage samples $(\mathrm{n}=380)$ obtained from 14 northeastern US organic dairies did not meet minimum NRC (2001) requirements of $\mathrm{Ca}, \mathrm{P}$, and $\mathrm{S}$ in 22 , 26 , and $7 \%$ of samples, respectively, during a modeling exercise in which Jersey cows were offered forage as the sole feed source (Hafla et al., 2016). Therefore, KM may be used as a supplemental source of minerals in pasture-based systems, particularly because of its high concentrations of $\mathrm{Ca}$ and $\mathrm{S}$. However, nutritionists and dairy producers should be aware that feeding $113 \mathrm{~g}$ of KM per cow daily would surpass I requirements, as discussed in detail below, suggesting that the overall diet needs to be formulated to minimize a chronic excess of I intake. Oceans are the richest source of I (Fuge and Johnson, 2015) due to leaching from the upper Earth's crust (Muramatsu and Wedepohl, 1998), and brown seaweed species are known to bioaccumulate I through uptake of iodide from seawater (Baily and Kelly, 1955; Küpper et al., 1998).

The concentration of GLS averaged 89.6, 34.1, and $80.1 \mathrm{mg} / \mathrm{kg}$ of DM in herbage, baleage, and concentrate blend, respectively (Tables 1 and 2). The variation in the concentrations of GLS observed in herbage and baleage fed in the present study likely reflects changes in herbage botanical composition of pastures and hayfields, respectively. According to Tripathi and Mishra (2007) and Osman et al. (2013), GLS are a group of sulfur-containing secondary plant compounds that, after degradation by the gut microbiota, yield thiocyanates and other derivatives known to competitively inhibit iodide uptake by the sodium iodide symporter into bodily tissues, including the thyroid and mammary glands, ultimately impairing the transfer of I to milk (Brown-Grant, 1957; Franke et al., 2009; Weiss et al., 2015). Approximately 120 different types of GLS have been identified across 16 families of dicotyledonous angiosperms, with species in the Brassicaceae family among the chief sources of GLS (Tripathi and Mishra, 2007; Osman et al., 2013).

\section{Feed Intake, Milk Yield, and BW}

Treatment effects on feed intake, milk yield, concentrations and yields of milk components, feed efficiency, BW gain, and BCS are presented in Table 3. Estimated herbage DMI was greater $(+1.2 \mathrm{~kg} / \mathrm{d} ; P=0.05)$ in cows fed the BSW diet compared with those fed the CTRL counterpart, whereas supplement DMI (pTMR DMI plus pellet DMI) was not affected by KM supplementation. Consequently, total DMI (herbage DMI 


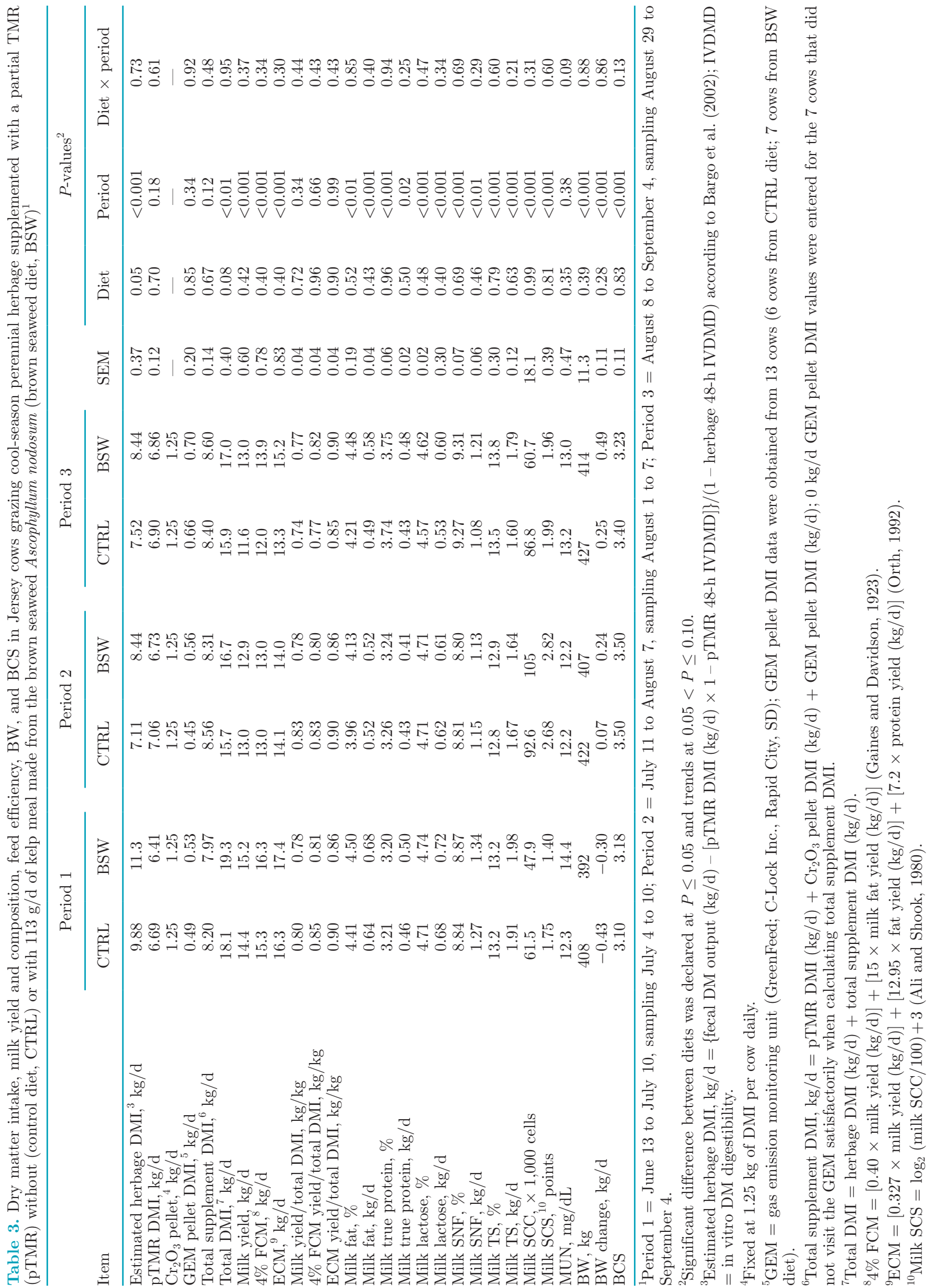


KELP MEAL SUPPLEMENTATION FOR GRAZING COWS

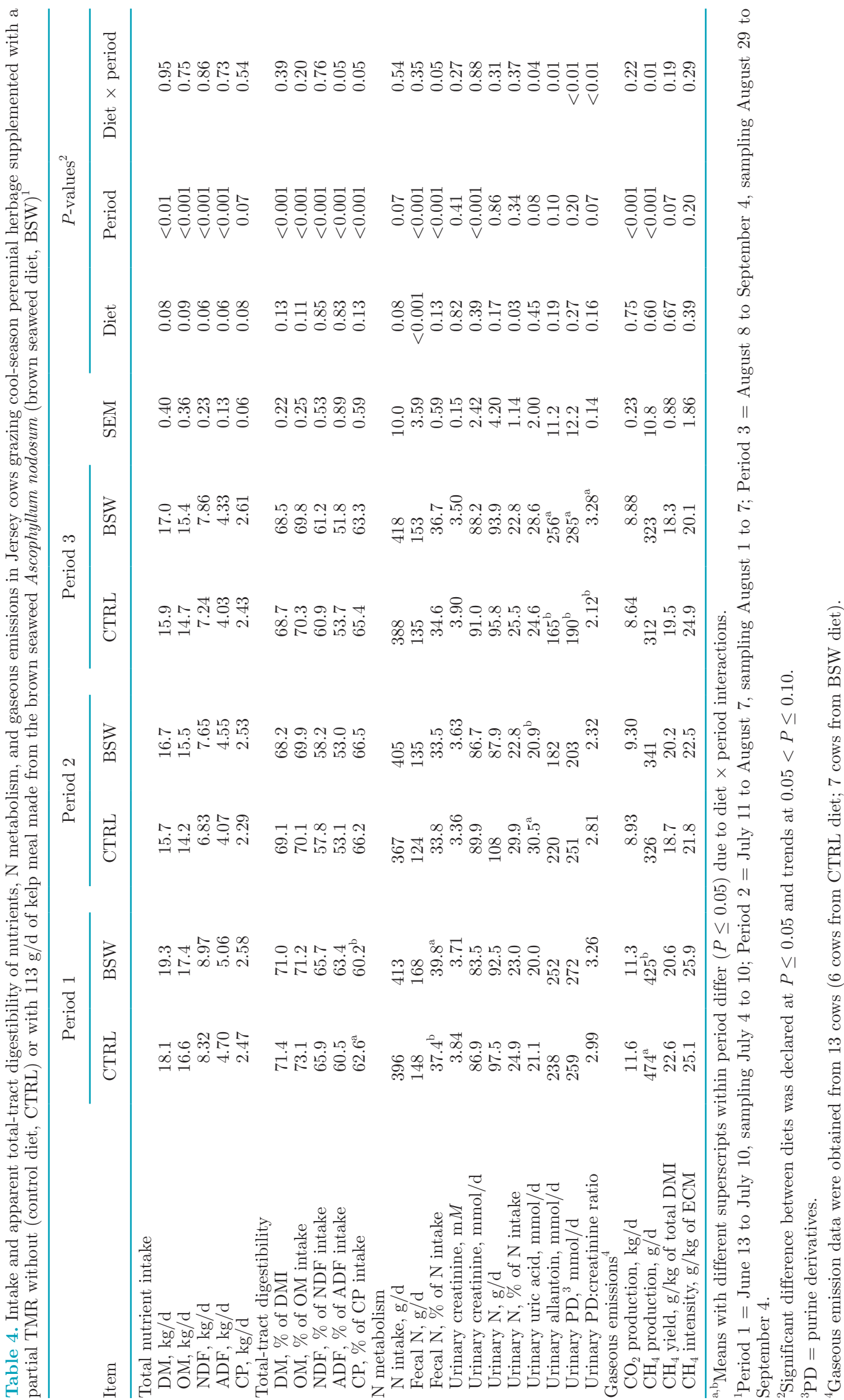


plus supplement DMI) tended $(P=0.08)$ to increase in grazing cows fed BSW versus CTRL. It is not clear why KM elevated herbage DMI in the present study. Additional Cr provided by KM supplementation $(0.11 \mathrm{mg} / \mathrm{d})$ was not sufficient to influence calculations of herbage DMI. However, limitations associated with $\mathrm{Cr}_{2} \mathrm{O}_{3}$ (e.g., cyclic changes in fecal Cr concentration) and IVDMD (assumed to be constant from animal to animal) add uncertainties to estimations of herbage DMI (Malossini et al., 1996; Mayes and Dove, 2000). Even though a diet $\times$ period interaction $(P=0.05$; Table 4$)$ was observed for the apparent total-tract digestibility of ADF, the actual difference between treatments was small and not consistent over time, thus likely not affecting herbage DMI.

Yields of milk $($ mean $=13.4 \mathrm{~kg} / \mathrm{d}), 4 \%$ FCM $($ mean $=13.9 \mathrm{~kg} / \mathrm{d})$, and ECM $($ mean $=15.1 \mathrm{~kg} / \mathrm{d})$ did not differ in cows fed CTRL versus the BSW diet. Likewise, feed efficiency and concentrations and yields of milk components (i.e., fat, true protein, lactose, SNF, TS) were not affected by treatments. Milk SCC and milk SCS also did not change due to diets. The lack of effect of KM supplementation on milk yield is not surprising because total DMI only tended to increase in cows assigned to the BSW diet. Information is scarce regarding the effects of KM on yields of milk and milk components in lactating dairy cows, and we are not aware of any experiment in which grazing dairy cows were supplemented with KM. Antaya et al. (2015) reported that neither milk yield nor concentrations and yields of milk components changed in response to incremental levels of KM, which agrees with studies where KM was supplemented at rates ranging from 56 to $132 \mathrm{~g} / \mathrm{d}$ (Pompeu et al., 2011) or at a fixed amount of $80 \mathrm{~g} / \mathrm{d}$ (Karatzia et al., 2012). In contrast, Cvetkovic et al. (2004) reported increased milk yield $(+1.7 \mathrm{~kg} / \mathrm{d})$ in dairy cows fed $57 \mathrm{~g} / \mathrm{d}$ of $\mathrm{KM}$ during the last $5 \mathrm{wk}$ of their experiment. Similarly, milk yield and $4 \%$ FCM improved by 10.5 and $11.9 \%$, respectively, in dairy cows supplemented with $50 \mathrm{~g} / \mathrm{d}$ of KM (Bendary et al., 2013). Kellogg et al. (2006) observed a breed $\times$ KM supplementation interaction, with the large-size cows (mostly Holsteins) producing more milk $(+2.3 \mathrm{~kg} / \mathrm{d})$ when offered KM (mean $=104 \mathrm{~g} / \mathrm{d}$ ), but no difference was found for the small-size counterparts (mostly Jerseys, Milking Shorthorns, and Holstein $\times$ Jersey crossbreeds). Positive responses in milk yield may be explained by the effects of $\mathrm{KM}$ on mitigating heat stress (Saker et al., 2001; Spiers et al., 2004; Archer et al., 2007; Pompeu et al., 2011) and its high concentrations of minerals and B-complex vitamins (Antaya et al., 2015). In fact, the studies of Cvetkovic et al. (2004), Kellogg et al. (2006), and Bendary et al. (2013) were all conducted during the hot summer months, and the control diet used by Bendary et al. (2013) was not balanced for minerals. The concentration of MUN (mean $=12.9 \mathrm{mg} / \mathrm{dL}$ ) did not differ in cows offered CTRL or BSW, which agrees with Antaya et al. (2015). Body weight, BW change, and BCS averaged $412 \mathrm{~kg}, 0.05$ $\mathrm{kg} / \mathrm{d}$, and 3.32 , respectively, and were similar between treatments (Table 3).

\section{Intake and Digestibility of Nutrients, Urinary N Excretion, and Gaseous Emissions}

Treatment effects on intake and apparent total-tract digestibility of nutrients, urinary excretion of nitrogenous metabolites, and gaseous emissions are presented in Table 4. Total intakes of OM, NDF, ADF, and CP followed total DMI and tended $(P \leq 0.09)$ to increase in cows fed BSW versus the CTRL diet. The apparent total-tract digestibilities of DM (mean $=69.5 \%)$, $\mathrm{OM}($ mean $=70.7 \%)$, and $\mathrm{NDF}($ mean $=61.6 \%)$ were not changed. However, diet $\times$ period interactions were found for the apparent total-tract digestibilities of ADF and CP. As discussed previously, despite the diet $\times$ period interaction for ADF digestibility, the actual difference between treatments was small and not consistent over time. The apparent total-tract digestibility of CP decreased in $\mathrm{P} 1(P=0.04)$ or tended $(P=0.06)$ to decrease in P3 in cows offered BSW versus the CTRL diet, with no difference between treatments in P2. Ascophyllum nodosum is the richest source of $\mathrm{PT}$ (Connan et al., 2004) known to resemble terrestrial tannins in their ability to bind proteins and carbohydrates (Ragan and Glombitza, 1986). Thus, PT in KM may have caused the drop in CP digestibility during $\mathrm{P} 1$, but it is unclear why no changes were detected in P2. Zhou et al. (2018) observed a linear decrease in the apparent total-tract digestibility of $\mathrm{CP}$ in sheep fed incremental amounts of $\mathrm{KM}(0,1$, or $3 \%$ of diet DM; $17.6,56.8$, or $101 \mathrm{~g} / \mathrm{d}$, respectively). Belanche et al. (2016a) demonstrated a $24 \%$ reduction in $\mathrm{N}$ digestion in fermentors dosed with $5 \%$ of the diet DM from KM, compared with CTRL, further reinforcing the depressive role of $\mathrm{PT}$ on ruminal proteolysis. The amount of $\mathrm{N}$ excreted in feces was elevated by $12.6 \%$ in cows offered BSW versus CTRL (Table 4), which is consistent with the PT mechanism of action.

Although the calculated amount of $\mathrm{N}$ excreted in urine $($ mean $=95.9 \mathrm{~g} / \mathrm{d})$ was not affected by diets, it was lower $(P=0.03)$ in BSW-fed versus CTRL-fed cows expressed as a proportion of $\mathrm{N}$ intake (Table 4). Therefore, it appears that $\mathrm{N}$ excretion was shifted from urine to feces when cows received the BSW diet, possibly mediated by PT present in KM, which is in line with decreased total-tract digestibility of $\mathrm{CP}$ and fecal $\mathrm{N}$ excretion as a proportion of $\mathrm{N}$ intake (Table 4). The 
urinary excretion of uric acid $(P=0.04)$, allantoin $(P$ $=0.01)$, and total $\mathrm{PD}(P<0.01)$, as well as the ratio of PD to creatinine $(P<0.01)$, resulted in diet $\times$ period interactions (Table 4). Except for the urinary excretion of uric acid, which decreased $(P=0.03)$ in cows offered the BSW diet in P2, excretion of allantoin, total PD, and the total PD:creatinine ratio increased $(P<0.01)$ in KM-supplemented cows in P3, and no differences were detected in P1 and P2. These interactions and the lack of a consistent effect of KM supplementation on the urinary excretion of PD are difficult to explain because variables known to affect microbial protein synthesis in the rumen, such as DMI and OM intake, only tended to increase in the BSW diet and did not follow a pattern similar to that observed for PD. Antaya et al. (2015) reported quadratic effects for the urinary excretion of allantoin, uric acid, and total PD, with cows fed 57 or $113 \mathrm{~g} / \mathrm{d}$ of KM showing the greatest values, suggesting that 0 or $170 \mathrm{~g} / \mathrm{d}$ of $\mathrm{KM}$ did not stimulate the growth of ruminal microbiota. Leupp et al. (2005) observed no change in the duodenal flow of bacterial $\mathrm{N}$ in beef steers offered poor-quality switchgrass (Panicum virgatum) hay supplemented with a cooked molasses block (341 $\mathrm{g}$ /daily) containing $10 \mathrm{~g}$ of KM. However, total bacterial population (number of $16 \mathrm{~S}$ rRNA gene copies/g of ruminal fluid) decreased linearly in rams fed amounts of KM (i.e., 17.6, 56.8, or $101 \mathrm{~g} / \mathrm{d}$; Zhou et al., 2018) greater than the level offered by Leupp et al. (2005).

The carbon emissions data presented in Table 4 were restricted to 13 cows (6 from CTRL and 7 from the BSW diet) and relied on 960 visits to the GEM unit during P1 to P3. According to Gunter and Beck (2018), 30 to 50 records per animal are needed to obtain high-quality estimates of gas fluxes using the GEM system under grazing conditions. The number of visits to the GEM unit by cows used in the current experiment averaged 74 . Although most of the remaining 7 cows accessed the GEM unit during the experiment, the number of visits was poor $(\leq 2$ times per cow/wk), and these measurements were not used in the statistical analysis. It is conceivable that this lower-than-expected number of visits by 7 cows could be related to the length of the alley gate $(\sim 30 \%$ longer than the cows' body length) used to individualize access to the GEM unit. In a subsequent study (A. F. Brito, unpublished data), visitation improved substantially with use of an alley gate that was comparable to the cows' body length.

No treatment effects were observed for $\mathrm{CO}_{2}$ production $($ mean $=9.78 \mathrm{~kg} / \mathrm{d}), \mathrm{CH}_{4}$ yield $($ mean $=20 \mathrm{~g} / \mathrm{kg}$ of total DMI), or $\mathrm{CH}_{4}$ intensity (mean $=23.4 \mathrm{~g} / \mathrm{kg}$ of ECM; Table 4). However, a diet $\times$ period interaction was detected for enteric $\mathrm{CH}_{4}$ production. Cows fed the BSW diet showed an $11.5 \%$ decrease $(P=0.04)$ in $\mathrm{CH}_{4}$ production during $\mathrm{P} 1$, but no changes were detected thereafter. This suggests a temporary effect of KM or an adaptation of the methanogenic community to the amount of KM fed over time. We are not aware of any in vivo study in which $\mathrm{CH}_{4}$ production was measured in ruminants fed KM. In vitro work has produced conflicting results. Whereas Belanche et al. (2016a) reported no effect of $\mathrm{KM}$ on $\mathrm{CH}_{4}$ production using the rumen simulation technique, $\mathrm{CH}_{4}$ production decreased quadratically in response to KM in a batch culture study (Belanche et al., 2016b). Moreover, Belanche et al. (2016a), in vitro, and Zhou et al. (2018), in vivo with rams, showed that KM inhibited the growth of ruminal methanogens. Therefore, ruminal archaea may have decreased in the present study, consistent with the drop in $\mathrm{CH}_{4}$ production in $\mathrm{P} 1$. It is worth noting that the amount of KM (up to $5 \%$ of the diet DM) used in the experiments of Belanche et al. (2016a) and Zhou et al. (2018) was much greater than that fed herein $(\sim 0.8 \%$ of total DMI). Dietary inclusion of $\mathrm{KM} \geq 1 \%$ of diet DM may not be practically feasible because of the risks to animal and human health associated with excess I intake, as discussed in detail below.

\section{lodine Metabolism and Glucosinolates Intake}

Intake of I and GLS, concentration and yield of milk I, and serum concentrations of the thyroid hormones $\mathrm{T}_{3}$ and $\mathrm{T}_{4}$ are presented in Table 5 . Herbage I intake was greater $(P=0.05)$ in cows fed BSW versus CTRL, which is consistent with increased herbage DMI $(P=$ 0.05; Table 3). Total I intake was elevated by $429 \%$ with feeding BSW, in response to I provided by KM, compared with the CTRL diet. According to the NRC (2001), the requirement of I for lactating dairy cows is $1.5 \mathrm{mg} / 100 \mathrm{~kg}$ of BW (NRC, 2001). The initial BW of cows used in the present study averaged $415 \mathrm{~kg}$, so the calculated I requirement is $6.23 \mathrm{mg} / \mathrm{d}$. This shows that the CTRL and BSW diets exceeded the I requirement by 184 and $1,404 \%$, respectively. The maximum tolerable concentration of dietary I, with consideration of animal health concerns, has been reported to be $50 \mathrm{mg} /$ $\mathrm{kg}$ of diet DM (NRC, 2005). Based on the mean total DMI of $17.1 \mathrm{~kg} / \mathrm{d}$ for cows in the current experiment, the maximum tolerable amount of I intake would be equivalent to $855 \mathrm{mg} / \mathrm{d}$, substantially greater than the total I intake reported in Table 5.

A diet $\times$ period interaction was observed for milk I concentration (Table 5). Cows offered the BSW diet had greater $(P<0.001)$ concentration of milk I during $\mathrm{P} 1$, $\mathrm{P} 2$, and P3 than those fed CTRL, but the largest difference $(+422 \%)$ between treatments was observed in P2, where milk I surpassed $500 \mu \mathrm{g} / \mathrm{L}$ in KM-supplemented cows. Total GLS intake was lowest during P2, which was likely caused by decreased GLS consumption from 
ANTAYA ET AL.

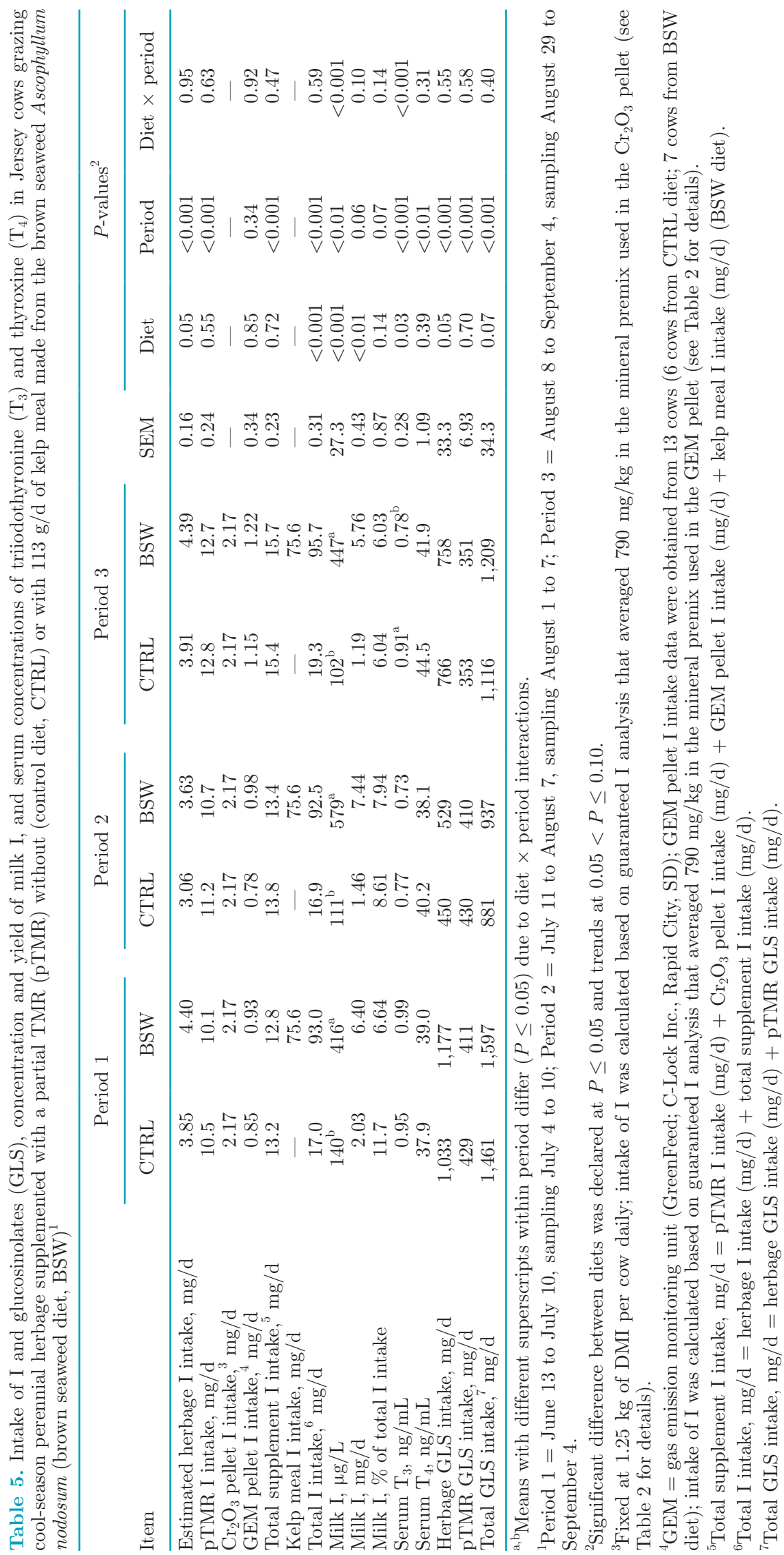




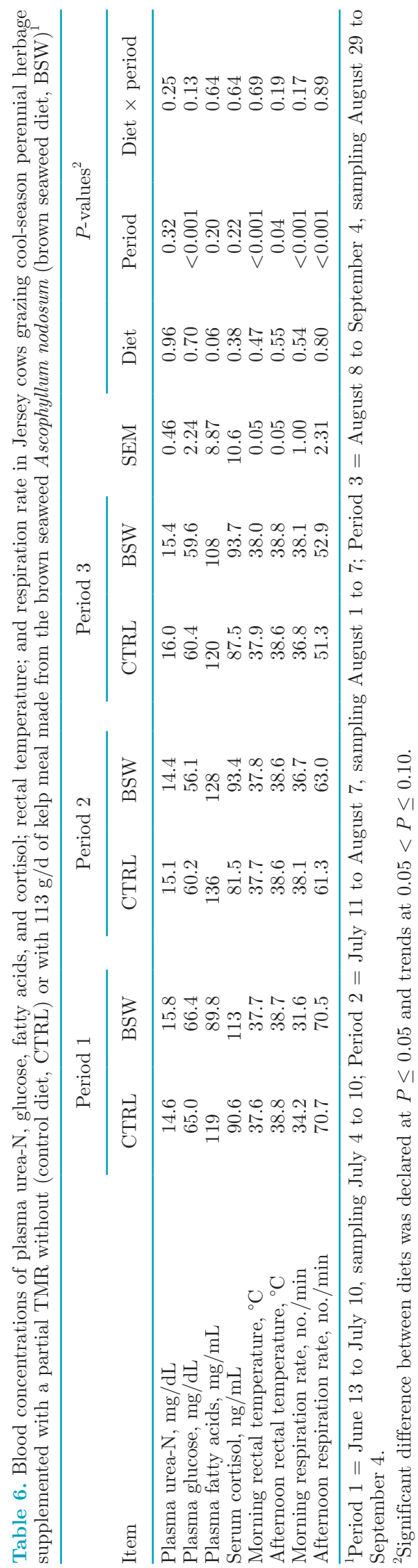

herbage (Table 5). Thus, the greatest disparity in milk I concentration between treatments in P2 is consistent with decreased GLS intake. Furthermore, the lowest GLS consumption may have resulted in proportionally less I uptake by the thyroid gland in cows fed BSW versus CTRL, leading to more I transfer to mammary tissues in P2 than P1 or P3, as no diet or diet $\times$ period interaction was seen for GLS intake (Table 5). Thiocyanates may also have played a role in the response of milk I to KM supplementation. More than 2,500 plant species, including white clover (the most predominant legume species found in the present study), can release hydrogen cyanide following the action of cyanogenic $\beta$-glucosidases (Crush and Caradus, 1995; Seigler, 1998; Osman et al., 2013), which become active after herbivory or damaged plant tissues (Gleadow and Woodrow, 2002). Detoxification of hydrogen cyanide by the ruminal microbiota and liver cells forms thiocyanates, known to be potent inhibitors of the binding of I in the thyroid gland (Greer et al., 1966). Collectively, our results indicate that dietary I should be monitored closely to avoid milk I concentrations exceeding the recommend $500-\mu \mathrm{g} / \mathrm{L}$ threshold considered safe for human consumption (EFSA, 2013). In a study conducted in the Canadian province of Quebec, $86 \%$ of the dairy farms $(\mathrm{n}=60)$ overfed I relative to the NRC (2001) recommendations (Borucki Castro et al., 2011).

Few studies have evaluated milk I concentration in dairy cows offered KM. Antaya et al. (2015) reported linear increases in the concentration (from 178 to 1,370 $\mu \mathrm{g} / \mathrm{L}$ ) and yield (from 2.82 to $20.6 \mathrm{mg} / \mathrm{d}$ ) of milk I in dairy cows supplemented with incremental amounts of KM, due to elevated I intake. Chaves Lopez et al. (2016) demonstrated a $113 \%$ increase in milk I concentration with feeding (\% of the diet DM) $2.3 \%$ of KM incorporated in a ground corn-based concentrate blend. In contrast, Sorge et al. (2016b) reported no effect of KM supplementation $(56 \mathrm{~g} / \mathrm{d})$ on milk I concentration. According to Sorge et al. (2016b), this lack of response was possibly caused by a baseline serum I concentration already above the reference range of 50 to $120 \mathrm{ng} /$ $\mathrm{mL}$ in their cows and an unexpected high I content in the TMR.

Based on the 2015-2020 Dietary Guideline for Americans (USDHHS-USDA, 2015), 2- to 3-yr-old children should consume 2 cup-equivalents $(\sim 473 \mathrm{~mL})$ of fat-free or low-fat milk daily as part of a healthy diet. This would result in $227 \mu \mathrm{g}$ of I consumption daily using the mean milk I concentration of $480 \mu \mathrm{g} / \mathrm{L}$ from cows supplemented with $113 \mathrm{~g} / \mathrm{d}$ of KM (Table 5). However, the same amount of KM $(113 \mathrm{~g} / \mathrm{d})$ resulted in milk I concentration of 1,015 $\mu \mathrm{g} / \mathrm{L}$ (Antaya et al., 2015), reflecting the well-documented seasonality of milk I due to changes in diets and management between summer 
and winter (Pennington 1990a; Walther et al., 2018). The tolerable upper intake limit for I consumption by 1 - to 3 -yr-old children is $200 \mu \mathrm{g} / \mathrm{d}$ (IOM, 2001). Therefore, children in this age group would be over the tolerable upper intake limit for I by 13.5 and $141 \%$ if consuming 2 cup-equivalents of milk with a concentration of 480 and $1,015 \mu \mathrm{g} / \mathrm{L}$, respectively. Even though chronic consumption of excess I does not generally represent an important public health concern in the United States (Pearce et al., 2004), it may increase the risk of thyroiditis, hyperthyroidism, hypothyroidism, and goiter in individuals with underlining thyroid issues or vulnerable groups (e.g., seniors, fetuses, neonates; Pennington, 1990b; Katagiri et al., 2017). Zimmermann et al. (2005) concluded that chronic I intake $(\geq 500$ $\mu \mathrm{g} / \mathrm{d}$ ) by school-aged children increased thyroid size. Recently, Aakre et al. (2017) reported an association between thyroid dysfunction and poor developmental status among children with excessive I intake. It should be noted that the consequences of prolonged exposure to excess I intake, particularly in children, are not well understood and require further investigation (Zimmermann et al., 2005; Katagiri et al., 2017).

Iodine deficiency represents a greater public health concern worldwide than I toxicity (Pearce et al., 2013), especially because I is essential for the synthesis of thyroid hormones that are involved in growth, development, and control of metabolic processes in the body. European research has demonstrated that the concentration of I in retail organic milk is lower than in conventional milk (e.g., Bath et al., 2012; ŚrednickaTober et al., 2016; Walther et al., 2018). This may reflect reduced use of mineral supplements and iodophor disinfectants in European organic dairies and reliance on pasture-based diets (Średnicka-Tober et al., 2016). Compared with the concentration of I in organic milk $($ mean $=147 \mu \mathrm{g} / \mathrm{L})$ reported in the meta-analysis of Srednicka-Tober et al. (2016), that of milk I (mean = $480 \mu \mathrm{g} / \mathrm{L}$; Table 5) in cows fed $113 \mathrm{~g} / \mathrm{d}$ of $\mathrm{KM}$ was $227 \%$ greater. Thus, KM may be a viable source of I for European organic dairy farms, if the goal is to make organic milk equivalent to conventional milk in I concentration. In the United States, pregnant women do not consume enough I, based on the median urinary I concentration $<150 \mu \mathrm{g} / \mathrm{L}$ (Sullivan et al., 2013). The US IOM (2001) recommends daily consumption of 220 $\mu \mathrm{g}$ of I for pregnant women, and adults in the country are recommended to consume 3 cup-equivalents $(\sim 710$ $\mathrm{mL}$ ) of fat-free or low-fat milk daily (USDHHS-USDA, 2015). Following these guidelines, pregnant adult American women would consume $341 \mu \mathrm{g}$ of I with 3 cup-equivalents of milk obtained from cows receiving $113 \mathrm{~g}$ of KM during the grazing season, $55 \%$ above the recommended $220 \mu \mathrm{g}$ of I daily (IOM, 2001). However,
US annual per capita consumption of $2 \%$ reduced-fat milk averages $22.7 \mathrm{~L}$ or $64 \mathrm{~mL} / \mathrm{d}$ (https://www.ers .usda.gov/data-products/food-availability-per-capita -data-system/; accessed Feb. 11, 2019). Consuming 64 $\mathrm{mL} / \mathrm{d}$ with milk I concentration of $480 \mu \mathrm{g} / \mathrm{L}$ would result in $31 \mu \mathrm{g}$ of I intake, $610 \%$ lower than the recommended $220 \mu \mathrm{g}$ of I for adult pregnant women in the US (IOM, 2001). Although milk is one of the major sources of I for Americans as well as for populations of other industrialized countries (Pearce et al., 2004; van der Reijden et al., 2017), ironically, consumption of whole fluid milk has declined steadily in the United States (https://www.ers.usda.gov/data-products/food -availability-per-capita-data-system/; accessed Feb. 11, 2019).

A diet $\times$ period interaction was observed for serum concentration of $\mathrm{T}_{3}$ (Table 5). Although no treatment differences were detected during P1 or P2, cows fed the BSW diet showed lower $(P<0.01)$ serum $\mathrm{T}_{3}$ in $\mathrm{P} 3$ than those offered CTRL. In contrast, serum concentration of $\mathrm{T}_{4}$ was similar with feeding CTRL or the BSW diet (Table 5). Compared with serum concentrations of $\mathrm{T}_{3}$ $($ mean $=1.09 \mathrm{ng} / \mathrm{mL})$ and $\mathrm{T}_{4}($ mean $=48.4 \mathrm{ng} / \mathrm{mL})$ in Jersey cows fed various amounts of KM during the winter season (Antaya et al., 2015), values in the current study were, on average, 26.7 and $20.1 \%$ lower, respectively. Variations in serum concentrations of $T_{3}$ and $T_{4}$ are driven by differences in environmental temperature, DIM, milk yield, and dietary goitrogens, among other factors (Aceves et al., 1987; Pezzi et al., 2003; Anderson et al., 2007). Sorge et al. (2016b) reported serum concentrations of $\mathrm{T}_{3}($ mean $=1.27 \mathrm{ng} / \mathrm{mL})$ and $\mathrm{T}_{4}$ (mean $=33.2 \mathrm{ng} / \mathrm{mL}$ ) in lactating Holstein cows fed KM that were greater and lower, respectively, than those measured herein. Even though serum $\mathrm{T}_{4}$ concentrations ( mean $=40.3 \mathrm{ng} / \mathrm{mL}$ ) in cows used in the present study were within healthy limits (29.5 to $44.3 \mathrm{ng} / \mathrm{mL}$ ) based on data from Holstein, that of serum $\mathrm{T}_{3}$ (mean $=0.86$ $\mathrm{ng} / \mathrm{mL}$ ) was not inside the normal range of 0.98 to 1.37-ng/mL (Kafi et al., 2012). As discussed earlier, cows fed the CTRL and the BSW diets consumed more I than required by 184 and 1,404\%, respectively. The fact that no treatment differences for serum $\mathrm{T}_{3}$ were found in P1 and P2 with feeding KM, but a decrease in this hormone occurred during P3, suggests that prolonged exposure to excess I intake may have affected the thyroid function. Previous research with dairy cows (Hillman and Curtis; 1980; Olson et al., 1984; Ong et al., 2014) showed that excess I intake, ranging from 45 to $600 \mathrm{mg} / \mathrm{d}$ for a minimum of $3 \mathrm{wk}$ up to $7 \mathrm{yr}$, led to toxicity signs. The consequences of excessive I intake on thyroid health varies from hyper- to hypothyroidism, with these outcomes likely dependent on the functional status of the thyroid gland preceding the onset of sur- 
plus I consumption (Pennington, 1990b). Even though no clinical signs of I toxicity were detected in the current experiment, cows fed KM did consume enough I $($ mean $=93.8 \mathrm{mg} / \mathrm{d})$ for a period $(>3 \mathrm{wk})$ that could have induced toxicity.

\section{Blood Metabolites and Physiological Parameters}

Treatment effects on concentrations of blood metabolites and physiological parameters are presented in Table 6. The concentration of PUN (mean $=15.2 \mathrm{mg} /$ $\mathrm{dL}$ ) followed that of MUN (Table 3) and did not differ between diets. Although the concentrations of glucose in plasma $($ mean $=61.3 \mathrm{mg} / \mathrm{dL})$ and cortisol in serum $($ mean $=93.3 \mathrm{ng} / \mathrm{mL})$ were similar with feeding CTRL versus the BSW diet (Table 3), that of plasma fatty acids tended $(P=0.06)$ to decrease in cows supplemented with KM. The plasma concentration of fatty acids dropped linearly, and that of cortisol tended to reduce linearly in response to various amounts of KM in the study of Antaya et al. (2015), conducted during the winter season. It is well known that cortisol and insulin have antagonistic mechanisms of action; when animals are experiencing stress, cortisol reduces cellular uptake of glucose, but this response is counteracted by lipolysis of the adipose tissue promoted by insulin (Munck et al., 1984; Sapolsky et al., 2000). However, blood concentrations of glucose and cortisol were not changed in the present experiment, suggesting that KM had no effect on mitigating stress from heat or nuisance flies during the grazing season.

Rectal temperature and respiration rates were not affected by treatments in the present study (Table 6). Previous research has showed that KM decreased respiration rate (Cvetkovic et al., 2004) and alleviated heat stress (Pompeu et al., 2011) in confined dairy cows during the summer, implying that these responses could be mediated by KM's role on body thermoregulation, even though the mechanism behind this potential effect is not well understood (Allen et al., 2001; Spiers et al., 2004). It should be acknowledged that rectal temperature and respiration rate measurements were not specifically planned to coincide with the hottest or most humid days during the summer in the current experiment. Studies under controlled temperature conditions are needed to provide further insights about the potential involvement of KM in heat stress abatement.

\section{CONCLUSIONS}

Milk I concentration increased in response to KM supplementation due to the high I content of this brown seaweed. Except during P2, the concentration of milk I did not surpass the recommend $500-\mu \mathrm{g} / \mathrm{L}$ threshold for human consumption, likely because of the presence of goitrogenic compounds such as GLS in the herbage grazed by the dairy cows. The lack of KM effects on milk yield, concentrations and yields of milk components, and stress- and animal health-related parameters such as blood cortisol, body temperature, and respiration rate, indicate that dairy producers should consider costs before making the decision to supplement cows with KM during the grazing season. Further research is warranted to elucidate the collective role of GLS and hydrogen cyanide derivatives on I metabolism in grazing dairy cows supplemented with KM, as well as the effects of KM on methanogenesis and $\mathrm{N}$ utilization. Research is also needed to evaluate the concentration of I in retail organic milk because of the high prevalence of KM supplementation in organic dairies in the northeastern and midwestern US and possibly other regions in the country.

\section{ACKNOWLEDGMENTS}

Partial funding was provided by the New Hampshire Agricultural Experiment Station. This is Scientific Contribution Number 2821. This work was also supported by the USDA National Institute of Food and Agriculture [Hatch Multistate NC-2042 (Project Number NH00616-R; Project Accession Number 1001855)] and Northeast SARE (Project Number GNE12-031, Durham, NH). The authors are grateful to Nancy L. Whitehouse (University of New Hampshire, Durham) for technical assistance, as well as to University of New Hampshire graduate and undergraduate students $\mathrm{Ni}$ cole Guindon, Trevor Beaudry, Brianna Isenberg, and Courtney Muir for support during sample collection. We also thank Thorvin Inc. (New Castle, VA) for donating the kelp meal used in the study. We finally thank the University of New Hampshire Burley-Demeritt Organic Dairy Research Farm former manager Trent Schrieffer and his staff for animal care and overall research support.

\section{REFERENCES}

Aakre, I., T. A. Strand, K. Moubarek, I. Barikmo, and S. Henjum. 2017. Associations between thyroid dysfunction and developmental status in children with excessive iodine status. PLoS One 12:e0187241. https://doi.org/10.1371/journal.pone.0187241.

Aceves, C., C. Romero, L. Sahagun, and C. Valverde-R.. 1987. Thyroid hormone profile in dairy cattle acclimated to cold or hot environmental temperatures. Acta Endocrinol. (Copenh.) 114:201-207. https://doi.org/10.1530/acta.0.1140201.

Ali, A. K. A., and G. E. Shook. 1980. An optimum transformation for somatic cell concentration in milk. J. Dairy Sci. 63:487-490. https: //doi.org/10.3168/jds.S0022-0302(80)82959-6.

Allen, G., K. R. Pond, K. E. Saker, J. P. Fontenot, C. P. Bagley, R. L. Ivy, R. R. Evans, R. E. Schmidt, J. H. Fike, X. Zhang, J. Y. Ayad, C. P. Brown, M. F. Miller, J. L. Montgomery, J. Mahan, D. 
B. Wester, and C. Melton. 2001. Tasco: Influence of a brown seaweed on antioxidants in forages and livestock-A review. J. Anim. Sci. 79:E21-E31. https://doi.org/10.2527/jas2001.79E-SupplE21x.

Anderson, P. D., B. Dalir-Naghadeh, and T. J. Parkinson. 2007. Iodine deficiency in dairy cattle. Proc. N.Z. Soc. Anim. Prod. 67:248-254.

Antaya, N. T., K. J. Soder, J. Kraft, N. L. Whitehouse, N. E. Guindon, P. S. Erickson, A. B. Conroy, and A. F. Brito. 2015. Incremental amounts of Ascophyllum nodosum meal do not improve animal performance but do increase milk iodine output in early lactation dairy cows fed high-forage diets. J. Dairy Sci. 98:1991-2004. https: //doi.org/10.3168/jds.2014-8851.

AOCS (American Oil Chemist Society). 2011. Determination of glucosinolate content in rapeseed and canola by HPLC. American Oil Chemist Society Official Method Ak 1-92. Am. Oil Chem. Soc., Urbana, IL.

Archer, G. S., T. H. Friend, D. Caldwell, K. Ameiss, and P. D. Krawczel. 2007. Effect of the seaweed Ascophyllum nodosum on lambs during forced walking and transport. J. Anim. Sci. 85:225-232. https://doi.org/10.2527/jas.2005-452.

Baily, N. A., and S. Kelly. 1955. Iodine exchange in Ascophyllum. Biol. Bull. 109:13-21. https://doi.org/10.2307/1538655.

Bargo, F., L. D. Muller, J. E. Delahoy, and T. W. Cassidy. 2002. Performance of high producing dairy cows with three different feeding systems combining pasture and total mixed rations. J. Dairy Sci. 85:2948-2963. https://doi.org/10.3168/jds.S0022-0302(02)74381 $-6$.

Bath, S. C., S. Button, and M. P. Rayman. 2012. Iodine concentration of organic and conventional milk: implications for iodine intake. Br. J. Nutr. 107:935-940. https://doi.org/10.1017/ S0007114511003059.

Belanche, A., E. Jones, I. Parveen, and C. J. Newbold. 2016a. A metagenomics approach to evaluate the impact of dietary supplementation with Ascophyllum nodosum or Laminaria digitata on rumen function in Rusitec fermenters. Front. Microbiol. 7. https:/ /doi.org/10.3389/fmicb.2016.00299.

Belanche, A., E. Ramos-Morales, and C. J. Newbold. 2016b. In vitro screening of natural feed additives from crustaceans, diatoms, seaweeds and plant extracts to manipulate rumen fermentation. J. Sci. Food Agric. 96:3069-3078. https://doi.org/10.1002/jsfa.7481.

Bendary, M. M., M. I. Bassiouni, M. F. Ali, H. M. Gaafar, and A. Sh. Shamas. 2013. Effect of premix and seaweed additives on productive performance of lactating Friesian cows. Int. Res. J. Agric. Sci. Soil Sci. 3:174-181.

Binnerts, W. T., A. T. Van't Klooster, and A. M. Frens. 1968. Soluble chromium indicator measured by atomic absorption in digestion experiments. Vet. Rec. 82:470-472.

Borucki Castro, S. I., P. Lacasse, A. Fouquet, F. Beraldin, A. Robichaud, and R. Berthiaume. 2011. Short communication: Feed iodine concentrations on farms with contrasting levels of iodine in milk. J. Dairy Sci. 94:4684-4689. https://doi.org/10.3168/jds .2010-3714

Brito, A. F. 2017. Invited commentary in response to the paper entitled 'Iodine concentration of milk-alternative drinks available in the UK in comparison with cows' milk' by Sarah Bath and colleagues. Br. J. Nutr. 118:879-880. https://doi.org/10.1017/ S0007114517003117.

Brito, A. F., K. J. Soder, P. Y. Chouinard, S. F. Reis, S. Ross, M. D. Rubano, and M. D. Casler. 2017. Production performance and milk fatty acid profile in grazing dairy cows offered ground corn or liquid molasses as the sole supplemental nonstructural carbohydrate source. J. Dairy Sci. 100:8146-8160. https://doi.org/10 $.3168 /$ jds.2017-12618

Brown-Grant, K. 1957. The iodide concentrating mechanism of the mammary gland. J. Physiol. 135:644-654. https://doi.org/10 .1113/jphysiol.1957.sp005736.

Casper, D. P., and D. R. Mertens. 2010. Carbon dioxide, a greenhouse gas, is sequestered by dairy cattle. J. Dairy Sci. 93(E-Suppl. 1):843-844. (Abstr.)

Chaves Lopez, C., A. Serio, C. Rossi, G. Mazzarrino, S. Marchetti, F. Castellani, L. Grotta, F. P. Fiorentino, A. Paparella, and G. Martino. 2016. Effect of diet supplementation with Ascophyllum nodosum on cow milk composition and microbiota. J. Dairy Sci. 99:6285-6297. https://doi.org/10.3168/jds.2015-10837.

Chen, X. B., Y. K. Chen, M. F. Franklin, E. R. Ørskov, and W. J. Shand. 1992. The effect of feed intake and body weight on purine derivative excretion and microbial protein supply in sheep. J. Anim. Sci. 70:1534-1542. https://doi.org/10.2527/1992.7051534x.

Chizzotti, M. L., S. C. Valadares Filho, R. F. D. Valadares, F. H. M. Chizzotti, and L. O. Tedeschi. 2008. Determination of creatinine excretion and evaluation of spot urine sampling in Holstein cattle. Livest. Sci. 113:218-225. https://doi.org/10.1016/j.livsci.2007.03 .013 .

Connan, S., F. Goulard, V. Stiger, E. Deslandes, and E. A. Gall. 2004 Interspecific and temporal variation in phlorotannin levels in an assemblage of brown algae. Bot. Mar. 47:410-416. https://doi.org/ 10.1515/BOT.2004.057.

Crush, J. R., and J. R. Caradus. 1995. Cyanogenesis potential and iodine concentration in white clover (Trifolium repens L.) cultivars. N. Z. J. Agric. Res. 38:309-316. https://doi.org/10.1080/00288233 .1995 .9513132 .

Cvetkovic, B., M. J. Brouk, and J. E. Shirley. 2004. Impact of dried seaweed meal on heat stressed lactating dairy cattle. Pages 59-61 in Dairy Day (Report of Progress 941). Kansas State University Agricultural Experiment Station and Cooperative Extension Service. Accessed Jan. 28, 2019. https://www.ksre.kstate.edu/ historicpublications/pubs/SRP941.pdf.

De La Vieja, A., O. Dohan, O. Levy, and N. Carrasco. 2000. Molecular analysis of the sodium/iodide symporter: Impact on thyroid and extrathyroid pathophysiology. Physiol. Rev. 80:1083-1105. https:/ /doi.org/10.1152/physrev.2000.80.3.1083.

Dorich, C. D., R. K. Varner, A. B. Pereira, R. Martineau, K. J. Soder, and A. F. Brito. 2015. Short communication: Use of a portable, automated, open-circuit gas quantification system and the sulfur hexafluoride tracer technique for measuring enteric methane emissions in Holstein cows fed ad libitum or restricted. J. Dairy Sci. 98:2676-2681. https://doi.org/10.3168/jds.2014-8348.

EFSA (European Food Safety Authority). 2013. Scientific opinion on the safety and efficacy of iodine compounds (E2) as feed additives for all animal species: Calcium iodate anhydrous and potassium iodide, based on a dossier submitted by Ajay Europe SARL. EFSA J. 11:3099-3133. https://doi.org/10.2903/j.efsa.2013.3099.

Franke, K., U. Meyer, H. Wagner, and G. Flachowsky. 2009. Influence of various iodine supplementation levels and two different iodine species on the iodine content of the milk of cows fed rapeseed meal or distillers dried grains with solubles as the protein source. J. Dairy Sci. 92:4514-4523. https://doi.org/10.3168/jds.2009-2027.

Fuge, R., and C. C. Johnson. 2015. Iodine and human health, the role of environmental geochemistry and diet, a review. Appl. Geochem. 63:282-302. https://doi.org/10.1016/j.apgeochem.2015.09.013.

Gaines, W. L., and F. A. Davidson. 1923. Relation between percentage fat content and yield of milk. Page 245 in Ill. Agric. Expt. Sta. Bull., University of Illinois, Urbana.

Gleadow, R. M., and I. E. Woodrow. 2002. Mini-Review: Constraints on effectiveness of cyanogenic glycosides in herbivore defense. J. Chem. Ecol. 28:1301-1313. https://doi.org/10.1023/A: 1016298100201.

Greer, M. A., A. K. Stott, and K. A. Milne. 1966. Effect of thiocyanate, perchlorate and other anions on thyroidal iodine metabolism. Endocrinology 79:237-247. https://doi.org/10.1210/endo-79 $-2-237$.

Gunter, S. A., and M. R. Beck. 2018. Measuring the respiratory gas exchange by grazing cattle using an automated, open-circuit gas quantification system. Transl. Anim. Sci. 2018:11-18. https://doi .org $/ 10.1093 /$ tas $/ \operatorname{txx} 009$.

Hafla, A. N., K. J. Soder, A. F. Brito, R. Kersbergen, A. F. Benson, H. M. Darby, M. D. Rubano, and S. F. Reis. 2016. Case study: Feeding strategy and pasture quality relative to nutrient requirements of dairy cows in the northeastern United States. Prof. Anim. Sci. 32:523-530. https://doi.org/10.15232/pas.2015-01500.

Hammond, K. J., D. J. Humphries, L. A. Crompton, C. Green, and C. K. Reynolds. 2015. Methane emissions from cattle: Estimates from short-term measurements using a GreenFeed system com- 
pared with measurements obtained using respiration chambers or sulphur hexafluoride tracer. Anim. Feed Sci. Technol. 203:41-52. https://doi.org/10.1016/j.anifeedsci.2015.02.008.

Hardie, C. A., M. Wattiaux, M. Dutreuil, R. Gildersleeve, N. S. Keuler, and V. E. Cabrera. 2014. Feeding strategies on certified organic dairy farms in Wisconsin and their effect on milk production and income over feed costs. J. Dairy Sci. 97:4612-4623. https://doi .org $/ 10.3168 /$ jds.2013-7763.

Hillman, D., and A. R. Curtis. 1980. Chronic iodine toxicity in dairy cattle: Blood chemistry, leukocytes, and milk iodide. J. Dairy Sci. 63:55-63. https://doi.org/10.3168/jds.S0022-0302(80)82887-6.

IOM (United States Institute of Medicine). 2001. Iodine. Pages 258289 in Dietary Reference Intakes. Report of the panel on micronutrients. Food and Nutrition Board. Natl. Acad. Press, Washington, DC. https://doi.org/10.17226/10026

Isenberg, B. J., K. J. Soder, A. B. D. Pereira, R. Standish, and A. F. Brito. 2019. Production, milk fatty acid profile, and nutrient utilization in grazing dairy cows supplemented with ground flaxseed. J. Dairy Sci. 102:1294-1311. https://doi.org/10.3168/jds.2018-15376.

Kafi, M., A. Tamadon, M. Saeb, A. Mirzaei, and M. Ansari-Lari. 2012. Relationships between thyroid hormones and serum energy metabolites with different patterns of postpartum luteal activity in high producing dairy cows. Animal 6:1253-1260. https://doi.org/ 10.1017/S1751731112000043.

Karatzia, M., E. Christaki, E. Bonos, C. Karatzias, and P. Florou-Paneri. 2012. The influence of dietary Ascophyllum nodosum on haematologic parameters of dairy cows. Ital. J. Anim. Sci. 11:169-173. https://doi.org/10.4081/ijas.2012.e31.

Katagiri, R., X. Yuan, S. Kobayashi, and S. Sasaki. 2017. Effect of excess iodine intake on thyroid diseases in different populations: A systematic review and meta-analyses including observational studies. PLoS One 12:e0173722. https://doi.org/10.1371/journal.pone .0173722 .

Kellogg, D. W., K. Anschutz, and J. Pennington. 2006. Report of research trial with Tasco at Rose Ark Dairy in Arkansas during summer 2005. Arkansas Animal Science Department Report Research Series 545. Univ. of Arkansas, Fayetteville. Accessed Jan. 20, 2019. http://arkansas-ag-news.uark.edu/pdf/545-20.pdf.

Kolver, E. S., and L. D. Muller. 1998. Performance and nutrient intake of high producing Holstein cows consuming pasture or a total mixed ration. J. Dairy Sci. 81:1403-1411. https://doi.org/10.3168/ jds.S0022-0302(98)75704-2.

Küpper, F. C., N. Schweigert, E. Ar, J. M. Gall, H. Legendre, H. Vilter, and B. Kloareg. 1998. Iodine uptake in Laminariales involves extracellular, haloperoxidase-mediated oxidation of iodide. Planta 207:163-171. https://doi.org/10.1007/s004250050469.

Leupp, J. L., J. S. Caton, S. A. Soto-Navarro, and G. P. Lardy. 2005. Effects of cooked molasses blocks and fermentation extract or brown seaweed meal inclusion on intake, digestion, and microbial efficiency in steers fed low-quality hay. J. Anim. Sci. 83:2938-2945. https://doi.org/10.2527/2005.83122938x.

MacArtain, P., C. I. R. Gill, M. Brooks, R. Campbell, and I. R. Rowland. 2007. Nutritional value of edible seaweeds. Nutr. Rev. 65:535-543. https://doi.org/10.1301/nr.2007.dec.535-543.

Makkar, H. P. S., G. Tran, V. Heuzé, S. Giger-Reverdinc, M. Lessire, F. Lebas, and P. Ankers. 2016. Seaweeds for livestock diets: A review. Anim. Feed Sci. Technol. 212:1-17. https://doi.org/10.1016/ j.anifeedsci.2015.09.018.

Malossini, F., S. Bovolenta, E. Piasentier, C. Piras, and F. Martillotti. 1996. Comparison of n-alkanes and chromium oxide methods for estimating herbage intake by grazing dairy cows. Anim. Feed Sci. Technol. 61:155-165. https://doi.org/10.1016/0377-8401(96)00954 $-6$.

Mayes, R. W., and H. Dove. 2000. Measurement of dietary nutrient intake in free-ranging mammalian herbivores. Nutr. Res. Rev. 13:107-138. https://doi.org/10.1079/095442200108729025.

Munck, A., P. Guyre, and N. Holbrook. 1984. Physiological functions of glucocorticoids in stress and their relation to pharmacological actions. Endocr. Rev. 5:25-44. https://doi.org/10.1210/edrv-5-1 -25 .
Muramatsu, Y., and K. H. Wedepohl. 1998. The distribution of iodine in the earth's crust. Chem. Geol. 147:201-216. https://doi.org/10 .1016/S0009-2541(98)00013-8.

National Research Council. 2001. Nutrient Requirements of Dairy Cattle. 7th rev. ed. Natl. Acad. Press, Washington, DC. https:// doi.org/10.17226/9825

National Research Council. 2005. Mineral Tolerance of Domestic Animals. 2nd rev. ed. Natl. Acad. Press, Washington, DC. https://doi .org/10.17226/25

Niu, M., E. Kebreab, A. N. Hristov, J. Oh, C. Arndt, A. Bannink, A. R. Bayat, A. F. Brito, T. Boland, D. Casper, L. A. Crompton, J. Dijkstra, M. A. Eugène, P. C. Garnsworthy, M. N. Haque, A. L. F. Hellwing, P. Huhtanen, M. Kreuzer, B. Kuhla, P. Lund, J. Madsen, C. Martin, S. C. McClelland, M. McGee, P. J. Moate, S. Muetzel, C. Muñoz, P. O'Kiely, N. Peiren, C. K. Reynolds, A. Schwarm, K. J. Shingfield, T. M. Storlien, M. R. Weisbjerg, D. R. Yáñez-Ruiz, and Z. Yu. 2018. Prediction of enteric methane production, yield, and intensity in dairy cattle using an intercontinental database. Glob. Chang. Biol. 24:3368-3389. https://doi .org/10.1111/gcb.14094.

Olson, W. G., J. B. Stevens, J. Anderson, and D. W. Haggard. 1984. Iodine toxicosis in six herds of dairy cattle. J. Am. Vet. Med. Assoc. $184: 179-181$.

Ong, C. B., T. H. Herdt, and S. D. Fitzgerald. 2014. Hyperplastic goiter in two adult dairy cows. J. Vet. Diagn. Invest. 26:810-814. https://doi.org/10.1177/1040638714554441.

Orth, R. 1992. Sample Day and Lactation Report. DHIA 200 FactSheet A-2. Mid-States DRPC, Ames, IA.

Osman, A. M. G., A. G. Chittiboyina, and I. A. Khan. 2013. Plant toxins. Pages 435-451 in Foodborne Infections and Intoxications. 4th ed. J. G. Morris Jr. and M. E. Potter, ed. Academic Press, London, UK.

Pearce, E. N., M. Andersson, and M. B. Zimmermann. 2013. Global iodine nutrition: Where do we stand in 2013? Thyroid 23:523-528. https://doi.org/10.1089/thy.2013.0128.

Pearce, E. N., S. Pino, X. He, H. R. Bazrafshan, S. L. Lee, and L. E. Braverman. 2004. Sources of dietary iodine: Bread, cows' milk, and infant formula in the Boston area. J. Clin. Endocrinol. Metab. 89:3421-3424. https://doi.org/10.1210/jc.2003-032002.

Pennington, J. A. 1990b. A review of iodine toxicity reports. J. Am. Diet. Assoc. 90:1571-1581.

Pennington, J. A. T. 1990a. Iodine concentrations in US milk: Variation due to time, season, and region. J. Dairy Sci. 73:3421-3427. https://doi.org/10.3168/jds.S0022-0302(90)79039-X.

Pérez-Prieto, L. A., and R. Delagarde. 2012. Meta-analysis of the effect of pregrazing pasture mass on pasture intake, milk production, and grazing behavior of dairy cows strip-grazing temperate grasslands. J. Dairy Sci. 95:5317-5330. https://doi.org/10.3168/ jds.2012-5609.

Pezzi, C., P. A. Accorsi, P. D. Vigo, N. Govoni, and R. Gaiani. 2003. 5 -Deiodinase activity and circulating thyronines in lactating cows. J. Dairy Sci. 86:152-158. https://doi.org/10.3168/jds.S0022 -0302(03)73595-4.

Pompeu, L. B., J. E. Williams, D. E. Spiers, R. L. Weaber, M. R. Ellersieck, K. M. Sargent, N. P. Feyerabend, H. L. Vellios, and F. Evans. 2011. Effect of Ascophyllum nodosum on alleviation of heat stress in dairy cows. Prof. Anim. Sci. 27:181-189. https://doi.org/ 10.15232/S1080-7446(15)30472-1

Ragan, M. A., and K. W. Glombitza. 1986. Phlorotannins, brown algal polyphenols. Pages 129-141 in Progress in Phycological Research. Vol. 4. F. E. Round and D. J. Chapman, ed. Biopress Ltd., Bristol, UK.

Resende, T. L., J. Kraft, K. J. Soder, A. B. D. Pereira, D. E. Woitschach, R. B. Reis, and A. F. Brito. 2015. Incremental amounts of ground flaxseed decrease milk yield but increase n-3 fatty acids and conjugated linoleic acids in dairy cows fed high-forage diets. J. Dairy Sci. 98:4785-4799. https://doi.org/10.3168/jds.2014-9115.

Rosenthal, H. L. 1955. Determination of urea in blood and urine with diacetyl monoxime. Anal. Chem. 27:1980-1982. https://doi.org/10 $.1021 /$ ac60108a039. 
Saker, K. E., V. G. Allen, J. P. Fontenot, C. P. Bagley, R. L. Ivy, R. R. Evans, and D. B. Wester. 2001. Tasco-Forage: II. Monocyte immune cell response and performance of beef steers grazing tall fescue treated with a seaweed extract. J. Anim. Sci. 79:1022-1031. https://doi.org/10.2527/2001.7941022x.

Sapolsky, R. M., L. M. Romero, and A. U. Munck. 2000. How do glucocorticoids influence stress responses? Integrating permissive, suppressive, stimulatory, and preparative actions. Endocr. Rev. 21:55-89. https://doi.org/10.1210/edrv.21.1.0389.

Seigler, D. S. 1998. Cyanogenic glycosides and cyanolipids. Pages 273-296 in Plant Secondary Metabolism. D. S. Seigler, ed. Kluwer Academic Press, Boston, MA. https://doi.org/10.1007/978-1-4615 $-4913-0 \_16$

Sorge, U. S., M. Henriksen, A. Bastan, N. Cremers, K. Olsen, and B. A. Crooker. 2016b. Short communication: Iodine concentrations in serum, milk, and tears after feeding Ascophyllum nodosum to dairy cows-A pilot study. J. Dairy Sci. 99:8472-8476. https://doi.org/ $10.3168 /$ jds.2015-10810.

Sorge, U. S., R. Moon, L. J. Wolff, L. Michels, S. Schroth, D. F. Kelton, and B. Heins. 2016a. Management practices on organic and conventional dairy herds in Minnesota. J. Dairy Sci. 99:3183-3192. https://doi.org/10.3168/jds.2015-10193.

Spiers, D. E., P. A. Eichen, M. J. Leonard, L. E. Wax, G. E. Rottinghaus, J. E. Williams, and D. P. Colling. 2004. Benefit of dietary seaweed (Ascophyllum nodosum) extract in reducing heat strain and fescue toxicosis: A comparative evaluation. J. Therm. Biol. 29:753-757.

Średnicka-Tober, D., M. Barański, C. J. Seal, R. Sanderson, C. Benbrook, H. Steinshamn, J. Gromadzka-Ostrowska, E. Rembiałkowska, K. Skwarło-Sońta, M. Eyre, G. Cozzi, M. K. Larsen, T. Jordon, U. Niggli, T. Sakowski, P. C. Calder, G. C. Burdge, S. Sotiraki, A. Stefanakis, S. Stergiadis, H. Yolcu, E. Chatzidimitriou, G. Butler, G. Stewart, and C. Leifert. 2016. Higher PUFA and n-3 PUFA, conjugated linoleic acid, $\alpha$-tocopherol and iron, but lower iodine and selenium concentrations in organic milk: A systematic literature review and meta- and redundancy analyses. Br. J. Nutr. 115:1043-1060. https://doi.org/10.1017/S0007114516000349.

Sullivan, K. M., C. Perrine, E. N. Pearce, and K. L. Caldwell. 2013 Monitoring the iodine status of pregnant women in the United States. Thyroid 23:520-521. https://doi.org/10.1089/thy.2012 .0217 .

Tripathi, M. K., and A. S. Mishra. 2007. Glucosinolates in animal nutrition: A review. Anim. Feed Sci. Technol. 132:1-27. https:// doi.org/10.1016/j.anifeedsci.2006.03.003.

USDHHS-USDA (U.S. Department of Health and Human Services and U.S. Department of Agriculture). 2015. 2015-2020 Dietary Guide- lines for Americans. 8th ed. Accessed Jan. 3, 2019. http://health .gov/dietaryguidelines/2015/guidelines/.

van der Reijden, O. L., M. B. Zimmerman, and V. Galetti. 2017. Iodine in dairy milk: Sources, concentrations and importance to human health. Best Pract. Res. Clin. Endocrinol. Metab. 31:385-395. https://doi.org/10.1016/j.beem.2017.10.004.

Walther, B., D. Wechsler, P. Schlegel, and M. Haldimann. 2018. Iodine in Swiss milk depending on production (conventional versus organic) and on processing (raw versus UHT) and the contribution of milk to the human iodine supply. J. Trace Elem. Med. Biol. 46:138-143. https://doi.org/10.1016/j.jtemb.2017.12.004.

Wang, Y., Z. Xu, S. J. Bach, and T. A. McAllister. 2008. Effects of phlorotannins from Ascophyllum nodosum (brown seaweed) on in vitro ruminal digestion of mixed forage or barley grain. Anim. Feed Sci. Technol. 145:375-395. https://doi.org/10.1016/j .anifeedsci.2007.03.013.

Wang, Y., Z. Xu, S. J. Bach, and T. A. McAllister. 2009. Sensitivity of Escherichia coli to seaweed (Ascophyllum nodosum) phlorotannins and terrestrial tannins. Asian-Aust. J. Anim. Sci. 22:238-245. https://doi.org/10.5713/ajas.2009.80213.

Weiss, W. P., D. J. Wyatt, D. H. Kleinschmit, and M. T. Socha. 2015. Effect of including canola meal and supplemental iodine in diets of dairy cows on short-term changes in iodine concentrations in milk. J. Dairy Sci. 98:4841-4849. https://doi.org/10.3168/jds.2014 $-9209$.

Wildman, E. E., G. M. Jones, P. E. Wagner, R. L. Boman, H. F. Troutt Jr., and T. N. Lesch. 1982. Dairy cow body condition scoring system and its relationship to selected production characteristics. J. Dairy Sci. 65:495-501. https://doi.org/10.3168/jds.S0022 -0302(82)82223-6.

Williams, C. H., D. J. David, and O. Iismaa. 1962. The determination of chromic oxide in faeces samples by atomic absorption spectrophotometry. J. Agric. Sci. 59:381-385. https://doi.org/10.1017/ S002185960001546X

Zhou, M., M. Hünerberg, Y. Chen, T. Reuter, T. A. McAllister, F. Evans, A. T. Critchley, and L. L. Guana. 2018. Air-dried brown seaweed, Ascophyllum nodosum, alters the rumen microbiome in a manner that changes rumen fermentation profiles and lowers the prevalence of foodborne pathogens. MSphere 3:e00017-e00018. https://doi.org/10.1128/mSphere.00017-18.

Zimmermann, M. B., Y. Ito, S. Y. Hess, K. Fujieda, and L. Molinari. 2005. High thyroid volume in children with excess dietary iodine intakes. Am. J. Clin. Nutr. 81:840-844. https://doi.org/10.1093/ ajcn/81.4.840. 